Article

\title{
An Event-Based Inventory Approach in Landslide Hazard Assessment: The Case of the Skolis Mountain, Northwest Peloponnese, Greece
}

\author{
Aspasia Litoseliti ${ }^{1}$, Ioannis K. Koukouvelas ${ }^{1, *(\mathbb{C})}$, Konstantinos G. Nikolakopoulos ${ }^{2}$ (1) \\ and Vasiliki Zygouri ${ }^{1}$ \\ 1 Department of Geology, Division of General, Marine Geology and Geodynamics, University of Patras, \\ 26500 Patras, Greece; aspal@upatras.gr (A.L.); zygouri@upatras.gr (V.Z.) \\ 2 Department of Geology, Division of Applied Geology and Geophysics, University of Patras, \\ 26504 Patras, Greece; knikolakop@upatras.gr \\ * Correspondence: iannis@upatras.gr; Tel.: +30-2610-996-157
}

Received: 19 June 2020; Accepted: 17 July 2020; Published: 20 July 2020

\begin{abstract}
Assessment of landslide hazard across mountains is imperative for public safety. Preand post-earthquake landslide mapping envisage that landslides show significant size changes during earthquake activity. One of the purposes of earthquake-induced landslide investigation is to determine the landslide state and geometry and draw conclusions on their mobility. This study was based on remote sensing data that covered 72 years, and focused on the west slopes of the Skolis Mountains, in the northwest Peloponnese. On 8 June 2008, during the strong Movri Mountain earthquake $(\mathrm{Mw}=6.4)$, we mapped the extremely abundant landslide occurrence. Historical seismicity and remote sensing data indicate that the Skolis Mountain west slope is repeatedly affected by landslides. The impact of the earthquakes was based on the estimation of Arias intensity in the study area. We recognized that 89 landslides developed over the last 72 years. These landslides increased their width $(\mathrm{W})$, called herein as inflation or their length $(\mathrm{L})$, termed as enlargement. Length and width changes were used to describe their aspect ratio $(\mathrm{L} / \mathrm{W})$. Based on the aspect ratio, the 89 landslides were classified into three types: I, J, and $\Delta$. Taluses, developed at the base of the slope and belonging to the J- and $\Delta$-landslide types, are supplied by narrow or irregular channels. During the earthquakes, the landslide channels migrated upward and downward, outlining the mobility of the earthquake-induced landslides. Landslide mobility was defined by the reach angle. The reach angle is the arctangent of the landslide's height to length ratio. Furthermore, we analyzed the present slope stability across the Skolis Mountain by using the landslide density (LD), landslide area percentage (LAP), and landslide frequency (LF). All these parameters were used to evaluate the spatial and temporal landslide distribution and evolution with the earthquake activity. These results can be considered as a powerful tool for earthquake-induced landslide disaster mitigation
\end{abstract}

Keywords: earthquake-induced landslides; inventory; remote sensing; aerial photographs; arias intensity; Greece

\section{Introduction}

A common approach for studying slope failure by an earthquake or cumulative earthquakes is the inventory of the induced landslides. Landslide inventory, according to Cruden [1] and Fell et al. [2] is the record of the location, classification, volume, activity, and date of occurrence, where known, of individual landslides in an area as inventory maps. Although inventory maps have received particular attention for landslide susceptibility, landslide maps cover less than $1 \%$ of the slopes in 
the landmasses, and systematic information on the type, abundance, and distribution of landslides is lacking. [3]. There are many criteria for long-term inventory maps depending on the purpose or the extent or the available remote sensing data (i.e., aerial photographs or satellite images) that contribute to its temporal completeness [4,5]. Furthermore, in the case of earthquake-induced landslides, the completeness of the records of local seismicity are also very important. Thus, it is necessary to have a consecutive time series of remote sensing and earthquake data to determine the reactivation and appearance of old and new landslides, respectively. According to Xu [6], landslide inventories based on remote sensing data can avoid missing a large number of small scale landslides and can obtain detailed and comprehensive earthquake-triggered landslide inventories.

Beginning in 1984, syntheses of worldwide and national data on earthquake-induced landslides have defined their general characteristics and relations between their occurrence and various geologic and seismic parameters [7]. For these reasons, the need to create databases that include parameters and landslide characteristics has become more intense. The latter led to the production of landslide inventories, which were associated with an isolated severe seismic event or the cumulative effects of events as trigger factors [8]. While most early workers have highlighted the importance of the inventories [9-13], the first well-known digital inventory map for earthquake-triggered landslides was compiled by Harp and Jibson [14]. Since then, many landslide inventories have been prepared in relation with moderate or strong earthquakes [3,6,7,14-21].

Three main techniques are used to correlate the landslide hazard to earthquakes. Inventory of landslide evolution over time is based on the geometrical characteristics of the earthquake-induced landslides [3,8,19,22-25], historical seismicity, and consideration of the Arias empirical intensity [26-28]. Since these three techniques involve a large amount of data, the mapping and analysis were implemented in a geographic information system (GIS). Furthermore for the qualitative and quantitative analysis of landslide distribution across a bluff, the estimation of the landslide density (LD), the landslide area percentage (LAP), and the landslide frequency (LF) over time is of particular importance. The LD expresses the number of landslides per square kilometer, the LAP is defined as the percentage of the area affected by landslides, and the LF is calculated by dividing the density of landslides by the analyzed time interval.

The work in this paper builds on the past work of Koukouvelas et al. [29], which presents abundant and isolated landslides induced during the 2008 Movri Mountain earthquake on the Skolis Mountain west slope. In [29], the authors examined the effect of different factors such as the morphology of the Skolis Mountain, the climate, the pre-existing faults, and the seismicity as triggering factors for landslides. The result was that slope angle and earthquakes are directly controlling the induced slope failures. Other slope factors like gradient, direction, length, and shape are slightly changing along the mountain, while factors like drainage density, rock types, structural data, etc. are not crucially significant factors.

In this work, we analyzed the landslides detected from aerial photographs or satellite images in a 72 year period as well as tried to highlight the role of seismicity on their temporal evolution. Our datasets comprise orthorectified aerial photographs and satellite images covering the period 1945-2017. In addition, we considered the Arias empirical relationships of all earthquake events with magnitudes above 4.0 in the NW Peloponnese to refine the events affecting the Skolis Mountain. A regression analysis was performed by correlating the number of landslides and their area, in order to consider if these two parameters have evolved over time. To improve the reliability of our landslide evolution model, we applied statistical analysis of the landslide evolution and quantitative analysis of the geometric characteristics of the landslides. This inventory, across a 10-km-long slope, is presented for the first time in Greece. Finally, we applied the length-width (aspect ratio) and height-length ratio (reach angle) of landslides when trying to introduce the future mobility of landslides in this study area. 


\section{Geological Setting}

On 8 June 2008, a strong earthquake of $\mathrm{Mw}=6.4$ struck northwest Peloponnese, called herein as the Movri Mtn earthquake [30,31] (Figure 1). The epicentral area of this earthquake incorporated a significant part of the NW Peloponnese while across the Skolis Mtn, extensive landslides and rockfalls were mapped [29,32]. Santomerion village, located on the west bluff of the Skolis Mtn, suffered by far the most damage due to landslides, among five others around the Skolis Mtn. These damages were due to the proximity of the village to steep slopes of the mountain (Figure 1). As steep slopes are commonly developed in limestone mountains in Greece [33], many Greek villages are prone to analogous risk during strong earthquakes. The earthquakes play a significant role in most of the slope failures (see also [9] for worldwide data, and [34,35] for Greek data). However, the exact role of earthquakes on the landslides in Greece is poorly understood. According to Keefer [7,9], moderate to strong earthquakes have long been recognized as a triggering factor of landslides. Earthquake-induced landslides can be either located on active faults or in the epicentral area $[9,35,36]$. Notably, an earthquake magnitude threshold for triggering landslides is 4.0 on susceptible slopes; while earthquakes with magnitudes greater than 6.0 can generate widespread landslides (see as an example Jibson and Keefer [37]). In mainland Greece, the recurrence interval of earthquakes of magnitude larger than 4.0 is short, and thus a significant part of the country is prone to earthquake-induced landslides. Consequently, the inventory studies of landslide prone-areas are crucial for civil protection purposes.

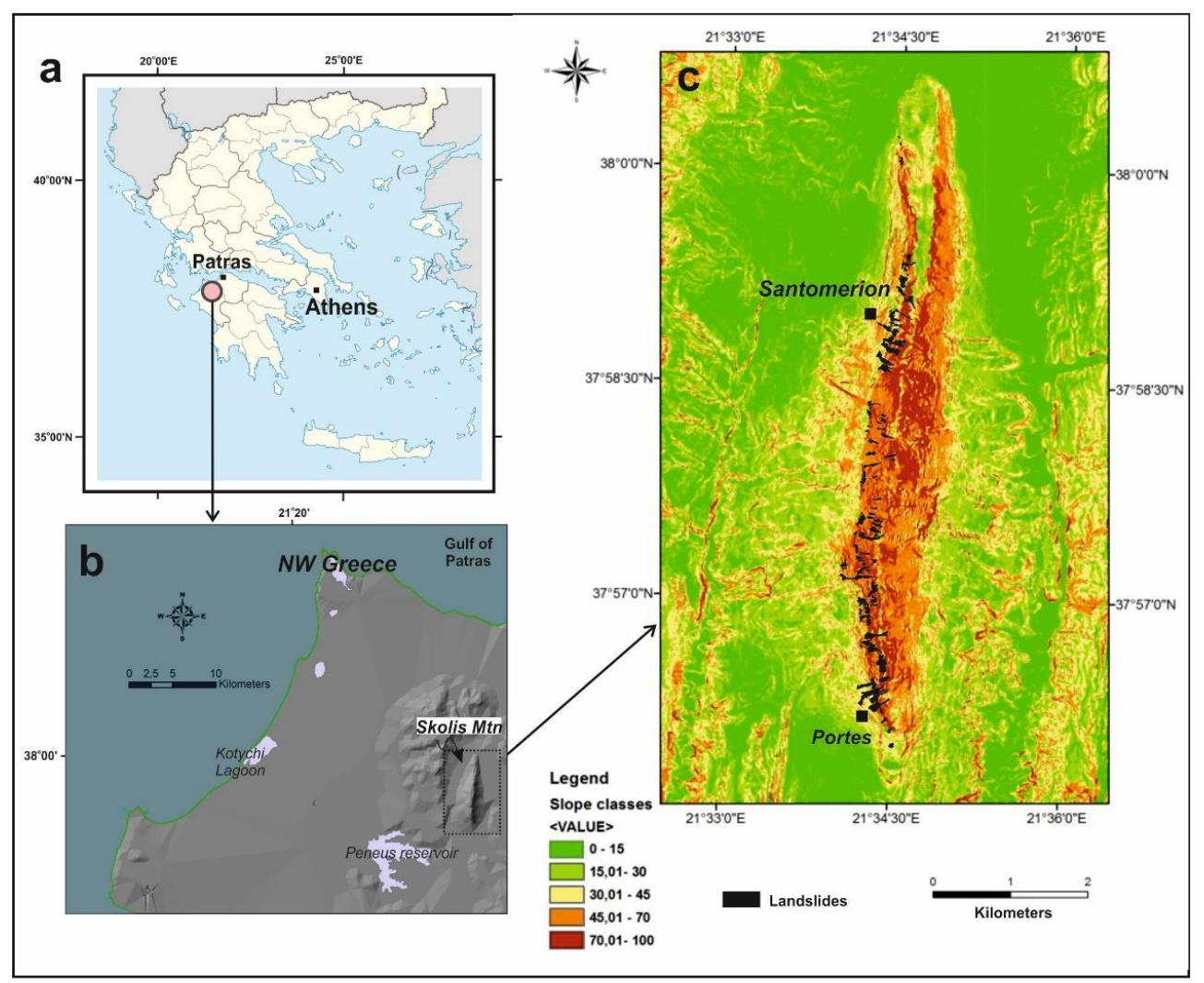

Figure 1. (a) Location map and (b) shaded relief map of the study area; (c) Slope map of Skolis Mountain.

NW Peloponnese and its surroundings are located within the most tectonic active and seismic region of Greece [38,39]. The Skolis Mtn developed as a fault-related-fold located at the tectonic boundary between the Ionian and Tripolitsa units [29]. The Skolis Mtn is an anticline almost 10-km-long, 1.5-km-wide with $\mathrm{N}-\mathrm{S}$ orientation characterized by a west-dipping short limb, and an east-dipping long limb (Figure 1). The mountain's morphology resembles its structure with its west bluff being short and steep while its east one is longer, dipping shallowly (Figure 1). 


\section{Materials and Methods}

In this work, we investigate and verify the spatial and temporal distribution of landslides across the Skolis Mtn between 1945 and 2017 (Figures 1-3). Aerial photographs of 1945 were selected as the base since they corresponded to the oldest available dataset in Greece. Satellite images from Google Earth during 2017 were the newest available data after a period of high seismicity in the area. For the entire inventory period, we used all the available aerial photographs and satellite data in this area, as described in Table 1. It is noteworthy that the acquisition of the remote sensing data used in this study is irregular in the analyzed time interval. In particular, 1945-2007 remote sensing data acquisition intervals range between 9-15 years; for the period 2007-2009, the data correspond to one image per year and for the period 2010-2017, correspond to two available datasets during 2015 and 2017.
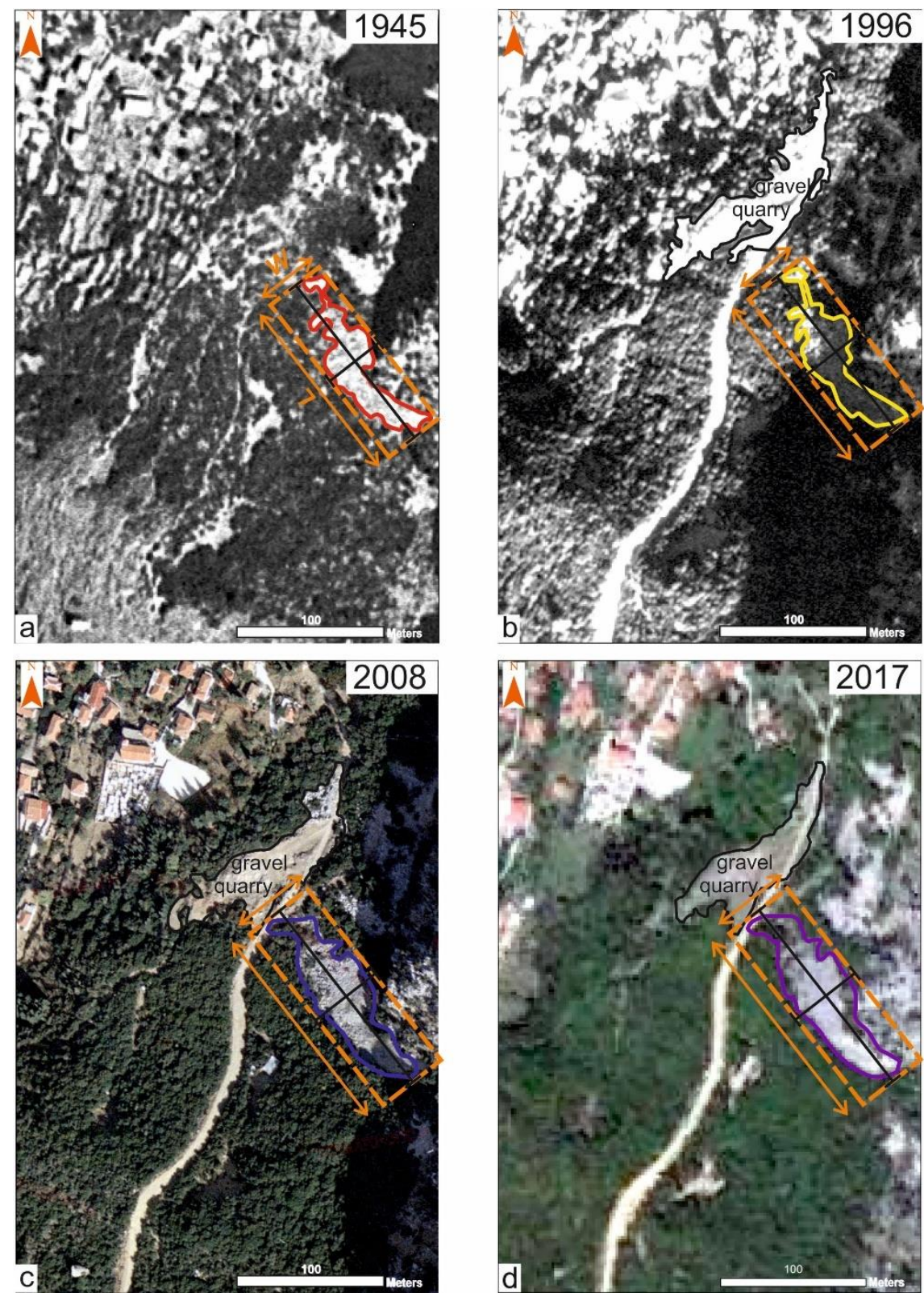

Figure 2. An example of the changes to landslide areas identified from the orthophotos. The orthophotos show, from (a-d), the perimeter of the digitized polygon area. Asymmetrical crosses (in black) represent the evolution of length and width that appeared in Figure 4. 
Framework of Skolis Model

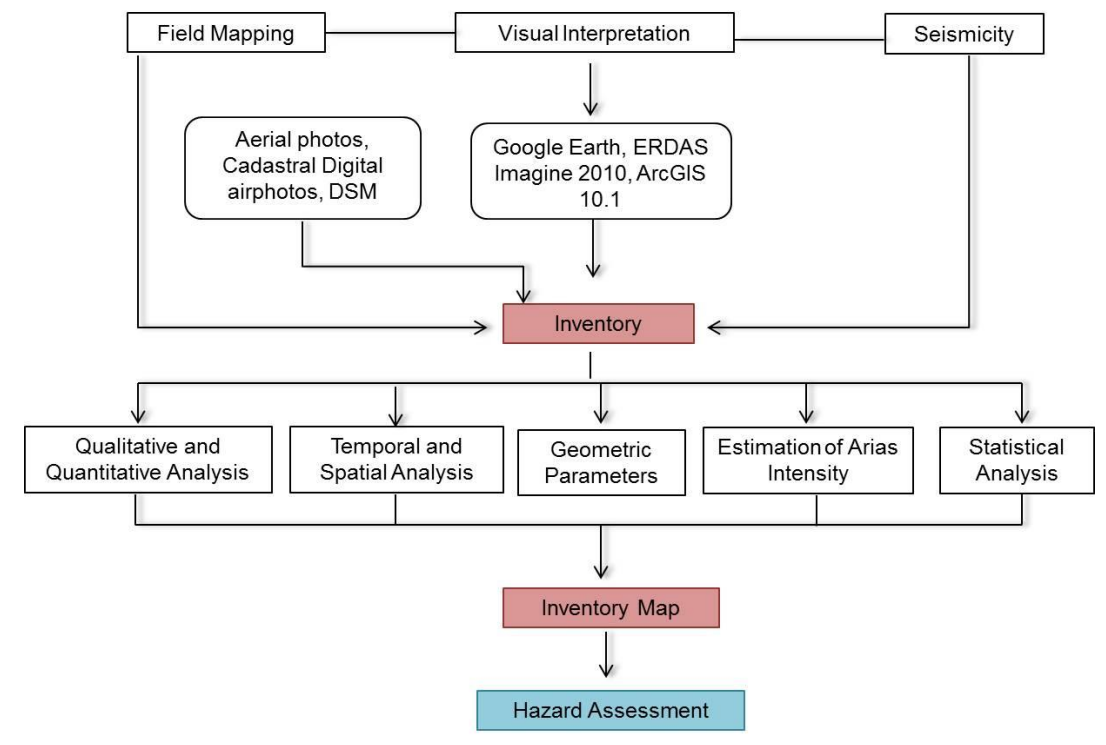

Figure 3. Flow chart that shows the steps of our methodology.

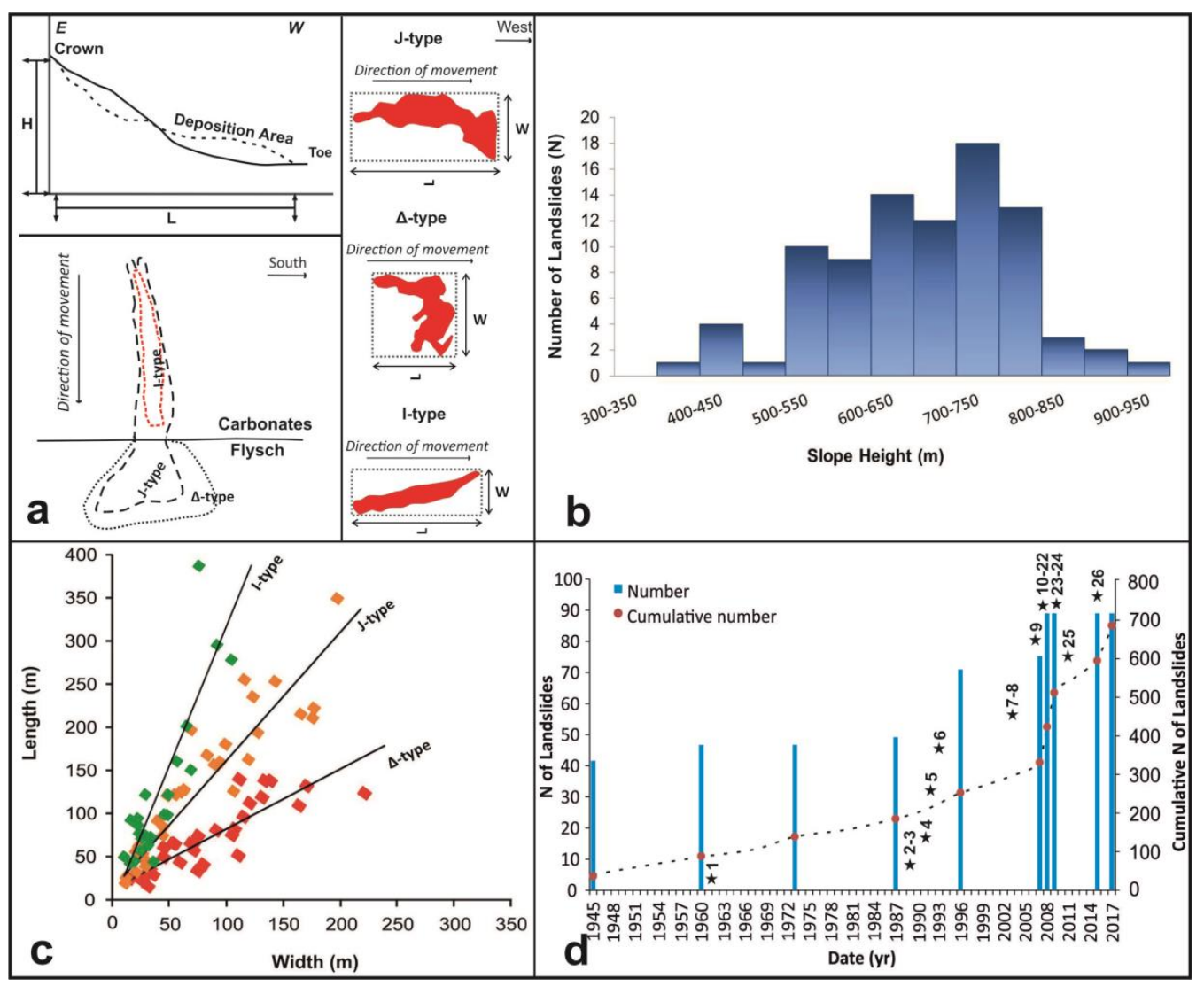

Figure 4. (a) Definitions of geometric parameters of Skolis Mtn landslides and the minimum bounding rectangle method; (b) Histogram showing the landslide spatial distribution in Skolis Mtn in terms of the crest height; (c) Plot showing the landslides aspect ratio during 2017. The solid black lines represent the best fit line between the length and width of the three landslide types of the table. (d) Chart showing the number (bars) and the cumulative number of landslides (dots) in the 1945-2017 time intervals. The stars show the earthquake events that appeared in Figure 8c. For the date of each earthquake, see Figure 8c. 
Overall, for the landslide inventory, we used ten (10) sets of remote sensing data. Geometric distortions, caused by viewing geometry and platform instability, are common in remotely sensed imagery. All aerial photographs were rthorectified to correct all possible geometric distortions following the methodology as described in Litoseliti et al. [40] and Koukouvelas et al. [29]. The digital orthomosaic and the digital surface model (DSM) from the National Greek Cadaster and Mapping Agency used as reference base maps for the selection of 84 ground control points for the orthorectification of all the other datasets.

Table 1. Seismicity and spatial resolution of the analogue aerial photographs (AAP), digital aerial photographs (DAP), and satellite images (SI) datasets used and their sources. Orange color represent periods of available aerial photographs and light green the lack of aerial photographs.

\begin{tabular}{|c|c|c|c|c|c|}
\hline Date * & $\begin{array}{l}\text { Seismicity } \\
\text { Periods }\end{array}$ & Data Type & Source & $\begin{array}{l}\text { Photos } \\
\text { Number }\end{array}$ & $\begin{array}{c}\text { Spatial } \\
\text { Resolution }\end{array}$ \\
\hline 1945 & \multirow{4}{*}{$\begin{array}{c}\text { NO } \\
\text { SEISMICITY }\end{array}$} & $\mathrm{AAP}^{1}$ & HMGS $^{2}$ & 2 & $1 \mathrm{~m}$ \\
\hline 1960 & & AAP & HMGS & 2 & $1 \mathrm{~m}$ \\
\hline 1973 & & AAP & HMGS & 1 & $1 \mathrm{~m}$ \\
\hline 1987 & & AAP & HMGS & 4 & $1 \mathrm{~m}$ \\
\hline 1988 & & \multirow{3}{*}{\multicolumn{4}{|c|}{ NO AQUISITION OF AERIAL PHOTOGRAPHS }} \\
\hline 1993 & SEISMICITY & & & & \\
\hline 1994 & \multirow{3}{*}{$\begin{array}{c}\text { NO } \\
\text { SEISMICITY }\end{array}$} & & & & \\
\hline 1996 & & Orthomosaics & HMGS & & $1 \mathrm{~m}$ \\
\hline 2002 & & \multirow{4}{*}{\multicolumn{4}{|c|}{ NO AQUISITION OF AERIAL PHOTOGRAPHS }} \\
\hline 2003 & SEISMICITY & & & & \\
\hline 2004 & NO & & & & \\
\hline 2006 & SEISMICITY & & & & \\
\hline 2007 & \multirow{3}{*}{ SEISMICITY } & $\mathrm{AAP} / \mathrm{SI}^{3}$ & HMGS, GE 4 & 2,1 & $1 \mathrm{~m}$ \\
\hline 2008 & & $\begin{array}{l}\text { DAP }{ }^{5} \text { orthomosaic, } \\
\text { field mapping, SI }\end{array}$ & $\begin{array}{l}\text { NGCMA }^{6} \\
\text { and GE }\end{array}$ & 1 & $0.5 \mathrm{~m}$ \\
\hline 2009 & & SI & GE & 1 & $0.65^{7} \mathrm{~m}$ \\
\hline 2010 & $\begin{array}{c}\text { NO } \\
\text { SEISMICITY }\end{array}$ & \multirow{4}{*}{\multicolumn{4}{|c|}{ NO AQUSITION OF AERIAL PHOTOGRAPHS }} \\
\hline 2011 & SEISMICITY & & & & \\
\hline 2012 & $\mathrm{NO}$ & & & & \\
\hline 2014 & SEISMICITY & & & & \\
\hline 2015 & SEISMICITY & SI & GE & 1 & $0.65 \mathrm{~m}$ \\
\hline 2016 & NO & \multicolumn{4}{|c|}{ NO AQUSITION OF AERIAL PHOTOGRAPHS } \\
\hline 2017 & SEISMICITY & SI & GE & 1 & $\mathrm{~m}$ \\
\hline
\end{tabular}

* Orange shading is for dates of orthomosaiscs. ${ }^{1} \mathrm{AAP}=$ Analogue aerial photographs; ${ }^{2} \mathrm{HMGS}=$ Hellenic Military Geographical Service; ${ }^{3} \mathrm{SI}=$ satellite images; ${ }^{4} \mathrm{GE}=$ Google Earth; ${ }^{5} \mathrm{DAP}=$ Digital aerial photographs; ${ }^{6}$ NGCMA = National Greek Cadaster and Mapping Agency; ${ }^{7}$ High resolution-imagery provided by satellite constellation of DigitalGlobe Tables may have a footer.

The base map orthomosaic has a spatial resolution of $0.5 \mathrm{~m}$, while the respective DSM has a spatial resolution of $5 \mathrm{~m}$ and a nominal vertical accuracy better than $2 \mathrm{~m}$. We also used Google Earth (GE) scenes as an additional tool for the spatial distribution of landslides. Note that although the horizontal positional accuracy of the GE data has questioned (i.e., [41,42]), the data of the GE scenes are used in many studies to produce landslide maps or landslide archives (e.g., [3,43-45]). Additionally, $\mathrm{Hu}$ et al. [46] proved that GE imagery provides similar classification results compared to the original Quickbird satellite images. In a recent study [47], it was proven that vectors derived from the GE images presented negligible differences in length derived from the orthorectified images. Characteristic 
examples are presented in Figure 2. The onscreen mapping of each landslide site on the remote sensing data was finally performed at the 1/1000 scale. First, the perimeter of each landslide was digitized and then isolated trees or tree stands were also digitized. Specific attention was paid during the landslide limits of digitization to exclude the canopy shadow into the tree stands and the bedrock into each slide area. Finally, the areas of the trees or tree stands were subtracted from the landslide polygon area. A detailed discussion on the whole methodology is described in Koukouvelas et al. [29].

In specific areas, the mapping completed by data given from the extra fieldwork. The fieldwork was focusing on mapping the outline of the borders of the landslide sites, particularly in areas of dense vegetation. The data stored in a GIS environment (ArcGIS 10.1). Considering the mentioned methods, Tables 2 and 3 summarize the landslide data in the studied area. In specific cases, we also used our laboratory archive photos and photos collected during the fieldwork after the 2008 earthquakes.

Table 2. Statistical parameters of the studied landslide sites on the west bluff of Skolis Mountain.

\begin{tabular}{|c|c|c|c|c|c|c|c|c|}
\hline Date & $\begin{array}{l}\text { Number of } \\
\text { Landslides } \\
\text { (N) }\end{array}$ & $\begin{array}{c}\text { New } \\
\text { Landslides } \\
\text { (N) }\end{array}$ & $\begin{array}{c}\text { Affected } \\
\text { Area } \\
\left(\mathrm{m}^{2}\right)\end{array}$ & $\begin{array}{c}\text { Landslide } \\
\text { Area } \\
\text { Percentage } \\
(\%) * *\end{array}$ & $\begin{array}{l}\text { Landslide } \\
\text { Density } \\
\left(\mathrm{N} / \mathbf{k m}^{2}\right)\end{array}$ & $\begin{array}{l}\text { Density of } \\
\text { New } \\
\text { Landslides } \\
\left(\mathrm{N} / \mathbf{k m}^{2}\right)\end{array}$ & $\begin{array}{c}\text { Interval } \\
(y r)\end{array}$ & $\begin{array}{l}\text { Landslide } \\
\text { Frequency } \\
\left(\mathrm{N} / \mathbf{k m}^{2 *} \mathrm{yr}\right)\end{array}$ \\
\hline 1945 & 42 & $\begin{array}{c}\text { Reference } \\
\text { datum }\end{array}$ & 33,496 & 0.86 & 10.77 & \multicolumn{3}{|c|}{ Reference datum } \\
\hline 1960 & 47 & 5 & 36,741 & 0.94 & 12.05 & 1.28 & 15 & 0.80 \\
\hline 1973 & 47 & 0 & 36,657 & 0.94 & 12.05 & 0.00 & 13 & 0.93 \\
\hline 1987 & 49 & 2 & 38,096 & 0.98 & 12.56 & 0.51 & 14 & 0.90 \\
\hline 1996 & 72 & 23 & 95,699 & 2.45 & 18.46 & 5.90 & 9 & 2.05 \\
\hline $\begin{array}{l}2007 \text { (13 } \\
\text { August) }\end{array}$ & 75 & 3 & 118,021 & 3.03 & 19.23 & 0.77 & 11 & 1.75 \\
\hline \multicolumn{9}{|l|}{2008 (15 } \\
\hline $\begin{array}{l}\text { May, } 10 \\
\text { July) }\end{array}$ & 89 & 14 & 242,198 & 6.21 & 22.82 & 3.59 & 1 & 22.82 \\
\hline $\begin{array}{c}2009 \text { (20 } \\
\text { July) }\end{array}$ & 89 & 0 & 269,109 & 6.90 & 22.82 & 0.00 & 1 & 22.82 \\
\hline $\begin{array}{c}2015 \text { (5 } \\
\text { May) }\end{array}$ & 89 & 0 & 278,969 & 7.15 & 22.82 & 0.00 & 6 & 3.80 \\
\hline $\begin{array}{l}2017 \text { (12 } \\
\text { August) }\end{array}$ & 89 & 0 & 292,918 & 7.51 & 22.82 & 0.00 & 2 & 11.41 \\
\hline Total & 89 & 47 & 292,918 & 7.51 & & & 72 & \\
\hline
\end{tabular}

** The percentage of landslide area is calculated with respect to the total area covered by landslides for the period 1945-2017.

Table 3. Temporal and spatial characteristics of the landslide sites from visual interpretation.

\begin{tabular}{ccccccc}
\hline \multicolumn{2}{c}{ Inventory } & \multicolumn{5}{c}{ Landslide Area $\left(\mathbf{m}^{\mathbf{2}}\right)$} \\
\hline Age & $\begin{array}{c}\text { Number of } \\
\text { Landslides (N) }\end{array}$ & $\begin{array}{c}\text { Affected } \\
\text { Area }\left(\mathbf{m}^{\mathbf{2}}\right)\end{array}$ & Min & Max & Mean & Std. Dev. \\
\hline 1945 & 42 & 33,496 & 50.64 & 5456.27 & 957.02 & 1108.21 \\
1960 & 47 & 36,741 & 58.62 & 5499.67 & 918.52 & 1121.23 \\
1973 & 47 & 36,657 & 58.62 & 5499.67 & 916.41 & 1118.71 \\
1987 & 49 & 38,096 & 58.62 & 5500.12 & 917.06 & 1119.26 \\
1996 & 72 & 95,699 & 58.78 & 8197.59 & 1519.04 & 1864.45 \\
2007 (13 August) & 75 & 118,021 & 58.80 & 8197.89 & 1639.17 & 1896.02 \\
2008 (15 May, 10 July) & 89 & 242,198 & 128.10 & $17,344.91$ & 2984.51 & 2990.01 \\
2009 (20 July) & 89 & 269,109 & 141.02 & $19,937.89$ & 3293.21 & 3321.11 \\
2015 (5 May) & 89 & 278,969 & 141.02 & $22,692.95$ & 3170.11 & 3716.50 \\
2017 (12 August) & 89 & 292,918 & 148.07 & $23,827.59$ & 3328.62 & 3902.32 \\
\hline Total & $\mathbf{8 9}$ & 292,918 & & & & \\
\hline
\end{tabular}

The spatial distributions of the landslides are presented as LD and LAP within the different orthomosaics. The qualitative analysis includes the geometrical characteristics of the landslide sites, and quantitative analysis focuses on their aspect ratio. 
The landslides in the Skolis Mtn are classified as fragmental rock falls, a term describing the movement of individual fragments that move as independent rigid bodies interacting with the substrate during episodical impacts [48]. These landslides are transitionally classified between rock falls and rock avalanching following Hungr et al. [49] and include individual fragments that descend slopes, bounce, and roll, while at a mean slope of $<30^{\circ}$ finally stop [50]. The continued occurrence of rock fragments produces a deposition zone of rock fall taluses or clusters of boulders downslope (Figures 2 and 4a). However, as rock falls, rock slides, and rock avalanches are sometimes difficult to distinguish one from the other, therefore, for simplicity, we will use the general term landslide in this study. These landslides are elongated showing (a) narrow rectilinear or (b) curvilinear paths, thus classified for brevity as I- or J-, respectively. The third type of landslides is classified as $\Delta$-shaped includes the elongate path and fan-shaped deposition area (Figure 4a). $\Delta$-shaped landslides are in common characterized by more than one landslide paths. In our case, these three types of landslides usually involve volumes smaller than $10^{5} \mathrm{~m}^{3}$.

Rainfall data in the Skolis Mtn area for half a century indicates that the period from April to September is almost dry with the high raining season concentrated from October to March. Testimonies of local people indicate strong consensus that landslide reactivation is a rather uncommon phenomenon, except at the beginning of the humid period (i.e., each October). The monthly precipitation varies from $8-60 \mathrm{~mm}$ in the dry period to $78-150 \mathrm{~mm}$ in October-March. Since the area is not prone to heavy rainfalls and floods, rainfall as a triggering factor appears to be less significant in comparison with the earthquakes. This suggestion is following the landslide mapping (Figures 2 and 3) where the post-2008 landslides are remaining dormant or stable for long after the Movri Mtn earthquake. In some cases, earthquakes act as predisposing factors while rainfall is considered the main trigger of landslides [51]. However, the Skolis case appears to be the opposite, where earthquakes are the main triggering factor [29] (see also Figures $4 \mathrm{~d}$ and 5). In particular, in Figure 4d, it can be observed that the number of landslides increased abruptly just after the 2008 earthquakes.

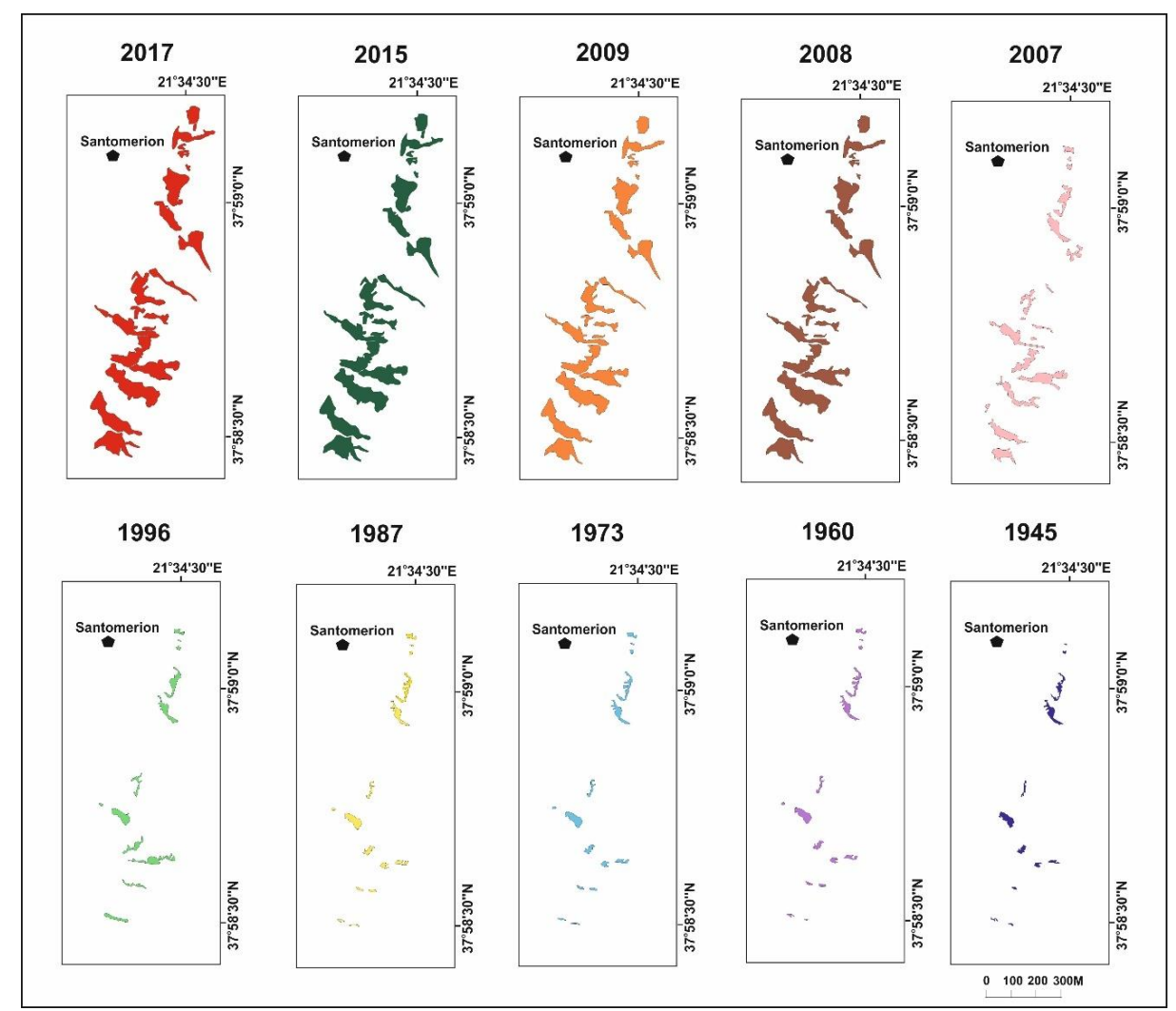

Figure 5. The evolution of the 21 landslides mapped from the orthomosaics during the 1945-2017 close to the Santomerion Village. 


\section{Landslide Inventory}

In total, across the Skolis Mtn over the 1945-2017 time intervals, we mapped 89 landslides affecting an area of $3.9 \mathrm{~km}^{2}$ (Figure 1). The affected area covers elevations from $350 \mathrm{~m}$ to $970 \mathrm{~m}$ (Figure $4 \mathrm{~b}$ ) with their length and width appearing in Figure 4c. These parameters, together with the height of the landslides, are primary data that consist of 267 measurements; 89 values for each parameter, as derived in 2017 orthophotomaps. Moreover, the diagram in Figure $4 \mathrm{~b}$ delineates the slope height as an important physical parameter that affects landslide occurrence. Additionally, $65 \%$ of the landslides were concentrated in the elevation range of $600-800 \mathrm{~m}$. To determine the rate of qualitative and quantitative landslide evolution, we composed ten inventory maps showing the interpretative landslide distribution during isolated earthquake events or their cumulative effects due to many earthquakes that left identifiable traces (Figures 5 and 6). For brevity, we present in Figure 5 ten maps analytically showing the evolution of 21 landslides for a $1500 \mathrm{~m}$ long part of the Skolis Mtn. This part of the mountain is the most significant since this is close to the Santomerion village.

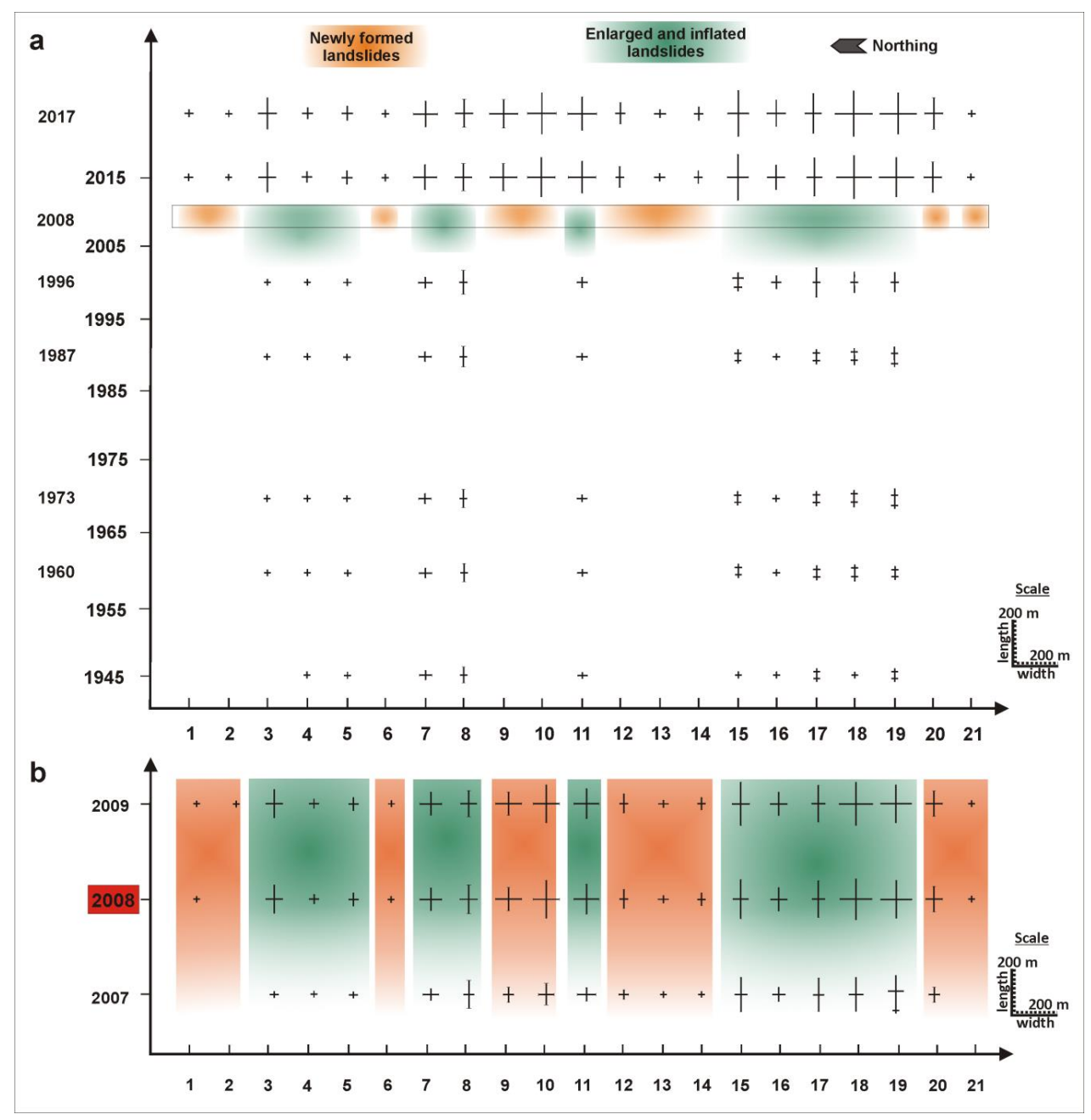

Figure 6. Map of length and width evolution of the 21 landslides appeared in Figure 5, in the Santomerion area. Crosses show dimensions of pre-earthquake landslide and their evolution over time. Asymmetrical crosses represent their inflation and/or enlargement, double crosses indicate coalescence of two or more landslides due to earthquake activity: (a) The orange rectangles show the newly formed landslides. The green rectangles show the evolved pre-earthquake landslides; (b) Mapping of the inflation and/or enlargement of 2008 earthquake triggered or reactivated landslides. The dark color indicates inflated and/or enlarged landslides after the 2008 earthquake, while the blur suggests more or less stable landslides. 
Apart from the qualitative and quantitative landslide evolution, Figure 6 indicates that even without seismic events, there is a slight increase in landslide area. In particular, high seismicity periods with enormous landslide increase are followed by a small landslide increase. A detailed example of the latter is depicted in Figure $6 a, b$ in landslide number 16. The estimated values of length and width relative to acquisition date were 45 and $44 \mathrm{~m}$ from 1945-1987, 85 and $71 \mathrm{~m}$ in 1996, 106 and $94 \mathrm{~m}$ in 2007, while they were 151 and $113 \mathrm{~m}$ in 2008, and 154 and 117 m from 2009-2017, respectively. Results showed an error of less than $2 \%$.

\section{Use of Randomly Acquired Aerial and Satellite Photographs for Landslide Inventory}

A common problem with past landslide inventories is that the aerial photographs were acquired at irregular time intervals commonly not for landslide inventory. In our case, from 1945 to 2007, the aerial photographs were acquired at time intervals ranging from 9 to 15 years in a random way (Table 1 and Figure 4d). Thus, our inventory periods are imposed by the acquired remote sensed data and so the proposed inventory does not cover isolated events, but rather a cluster of events. As aerial photography data are non-repeatable, it is a real challenge to try to study landslides with biased data. Furthermore, this challenge is more complicated when the aerial photographs are intercalated in a time series with earthquakes that trigger landslides. As an example in the case of the earthquake events from 1989-1993, the closest aerial photographs were acquired during 1996, and thus our analysis is not detailed enough. Thus, for the cluster of the 1989-1993 earthquakes, we used an orthophoto map during 1996. In the same period between 1993 and 1996, there was no earthquake activity, so we considered that the orthophoto map of 1996 was interpretative of the slope failures from 1989-1993.

However, there is a question posed, of what happens when earthquakes and seismic quiescence are repeated every second year like in the period from 2010-2017? Trying to address this question, there are two orthophoto maps during 2008 and 2009. These maps show that even in these two years, the seismic activity was intensive and the landslide evolution was rather limited. This suggestion indicates that either our method was not detailed enough to monitor the landslide evolution annually, or the recorded landslides have slowly been evolved. Nevertheless, if this result is correct, then it is highly possible to consider that the orthophoto map of 1996 is more or less interpretative of slope failures during the period from 1989-1993, and similarly, the orthophoto map of 2007 showed the role of the seismicity during the 2003 seismic period on the landslides across the Skolis Mtn. In particular, our landslide inventory included two well defined periods of seismic quiescence from 1945-1987 and 1994-2002. The rest of the 72 years was discriminated in seismic periods. The 2010-2017 landslide inventory period was characterized by an overall progressive decrease in seismicity in a stepwise manner. Therefore, we considered this alternation of earthquakes and seismic quiescence as a third motif affecting the evolution of the Skolis Mtn slope failures. This motif includes a seismicity decrease in a stepwise manner with an earthquake every second year or so, that lasts for eight years. At present, the seismicity in the area is absent. Summarizing, within the 72 years, we recognized two well defined periods of seismic quiescence in the order of eight and 42 years. Each seismic quiescence, followed by three short periods of seismicity, outlasting 5, 4, and 2 years. During the last seven-year-long period, the seismicity occurred almost every second year or so (Figures 5 and 6 and Table 1). Based on these data, the herein presented inventory can be considered as an event(s)-based one.

\subsection{Seismic Quiescence Period 1945-1987}

Over the first 42-years of the landslide inventory period, only an earthquake was recognized in reasonable distance and magnitude from Skolis Mtn during 1960 (Figure 5 and Figure 8). Consequently, the inventory maps of the landslides showed remarkable stability in their number and dimensions. This 42 year period shows that the majority of the landslides ( $86 \%$ ) were inactive, while $14 \%$ showed minor changes. The LAP over this period displayed values of $0.86 \%$ during 1945 and $0.98 \%$ during 1987. The LD has increased from 10.77 to 12.56 landslides $/ \mathrm{km}^{2}$, over these 42 years (Table 2). 


\subsection{Seismic Period $1988-1993$}

Five earthquake events above 4.6 inflicted the study area from 1988-1993 with three of the earthquakes above 5.2 (Figure 8 and Table 1). These events triggered 23 new landslides appeared in the 1996 orthomosaic (Table 2 and Figure 5). In this time period, the LAP increased by $150 \%$ and the occupied area increased from 38.096 to $95.699 \mathrm{~m}^{2}$ (Tables 2 and 3; Figures $4 \mathrm{~d}$ and 5). Therefore, in the 1987-1993 time-interval, landslide triggering appears to have occurred under a cluster of seismic events within epicentral distances in the order of $5-10 \mathrm{~km}$. In this time interval, LD increased proportionally with the increase in LAP from 12.56 to 18.46 landslides $/ \mathrm{km}^{2}$ and from 0.98 to $2.45 \%$, respectively (Table 2).

\subsection{Seismic Quiescence 1994-2002}

The chronological gap in our data was due to the lack of available aerial photographs and coincided with the observed absence of seismicity (Figure 8c). Recognizing this limitation, the analysis of this period has processed concerning possible biases. Since the next seismic sequence appeared in 2003, we cannot assert a change in landslide area during 1994-2002.

\subsection{Seismic Period 2003-2007}

As discussed earlier, the slope failures of the multiple events of 2003 were mapped in the orthophoto map of 2007 (Figure 8c). More specifically, the 2007 orthomosaic landslide activity was recognized as moderate when compared to those of the previous period. Particularly, the affected area changed from 95.699 to $118.020 \mathrm{~m}^{2}$, showing an increase of $23 \%$ (Tables 2 and 3).

\subsection{Seismic Period 2007-2009}

The analysis of this period is represented by three orthomosaics composed of several GE scenes in a high seismicity period (Table 1 and Figure 5). Furthermore, the use of 2007 and 2008 aerial photographs, and the orthophoto maps of this year was completed by field data. Regarding this period, two conclusions have been made: (i) after the Movri Mtn earthquake, a significant increase of the number of landslides is recognized, accounting for nearly one-quarter of new landslides developed in the Skolis Mtn; and (ii) a dramatic increase in the affected area from 118.020 to $242.198 \mathrm{~m}^{2}$. Moreover, the LAP and the LD showed an increase of $109 \%$ and 19\%, respectively (see Table 2). We also concluded that the $\mathrm{Mw}=6.4$ event was, beyond any doubt, a severe series of earthquakes that triggered 14 new landslides in the Skolis Mtn (Table 2).

\subsection{Seismic Period 2010-2017}

Observations of the 2010-2017 period show that a minor increase in landslide distribution in the order of $5 \%$ indicate the positive correlation between seismicity and landslides (Figures 5 and $8 \mathrm{~b}$ and Table 2). This was possibly due to moderate earthquakes (Figure 8b). The LAP increased by $9 \%$, while the LD remained stable.

\section{Results}

\subsection{Geometric Parameters of Skolis Landslides-Aspect Ratio}

The geometric analysis of the measured landslides is based on their length $(\mathrm{L})$ equal to the maximum distance from the toe to the crown and the width $(\mathrm{W})$ as the maximum amplitude perpendicular to their length (L). Another parameter that characterizes landslides is their height $(\mathrm{H})$, defined as the elevation difference between the landslide crown and the toe [52]. We used GIS software to obtain the $\mathrm{L}, \mathrm{W}$, and $\mathrm{H}$ parameters. From this perspective, we calculated the aspect ratio and the reach angle of the landslides. The aspect ratio is defined as the landslide length to width $(\mathrm{L} / \mathrm{W})$. The reach angle is the arctangent value of the height-length ratio $(\mathrm{H} / \mathrm{L})$. To estimate the aspect ratio $(\mathrm{L} / \mathrm{W})$, we created a 
minimum bounding rectangle that enclosed the corresponding values of length and width for each landslide site along the direction of movement [52,53] (Figure 4a).

Two significant results are outlined by aspect ratio analysis. First, the aspect ratio is changing over time. Second, each type of landslide has quite a discrete aspect ratio (Figure 4c). Overall, the aspect ratios vary in the range of $0.4 \leq(\mathrm{L} / \mathrm{W}) \leq 5.2$, with a mean value of 1.8. In particular, the 89 landslides based on the aspect ratio are classified as I-, J-, or $\Delta$-type, indicating the following ratios, I-type landslide $2.2 \leq(\mathrm{L} / \mathrm{W}) \leq 5.2$, and J-type landslides $1.2 \leq(\mathrm{L} / \mathrm{W})<2.2$ (see Table in Figure 7). I- and J-type landslides start at high elevation steep slopes of the mountain, also indicating the longer runout distances. The $\Delta$-type landslide shows the ratio $(\mathrm{L} / \mathrm{W})<1.2$ at moderately inclined slopes. I- and J-type landslides correspond to $64 \%(N=57)$ and are the dominant type identified near the Santomerion village, the most important area in terms of hazard (Figure 8a).

At the Santomerion area, the aspect ratio increased over time from 1996-2017, primarily in the I- and J-type landslides (Figures 6 and $7 \mathrm{~b}$ ). The I-type landslide shows primarily a length increase in the order of $13-30 \%$. In contrast, the J-type landslides, over the same time period, are bimodal, characterized either by predominant length or width increase (Figure $7 \mathrm{~b}$ ). Particularly important is that the J-type landslide shows significant mobility and increase in their length or width in the order of $100-500 \%$ (Figure $7 b$ ).

\begin{tabular}{c|c|c|c|c}
\hline $\begin{array}{c}\text { Landslide } \\
\text { Type }\end{array}$ & $\begin{array}{c}\text { Landslide } \\
\text { Number (N) }\end{array}$ & $\begin{array}{c}\text { Elevation } \\
\text { from min to } \max (\mathbf{m})\end{array}$ & $\begin{array}{c}\text { Aspect Ratio } \\
\text { (L/W) }\end{array}$ & $\begin{array}{c}\text { Percentage } \\
\text { (\%) }\end{array}$ \\
\hline$\Delta$-type & 32 & $390-825$ & $0.4 \leq \mathrm{L} / \mathrm{W}_{\Delta-\mathrm{t}}<1.2$ & 36.0 \\
\hline J-type & 34 & $400-880$ & $1.2 \leq \mathrm{L} / \mathrm{W}_{\mathrm{J}-\mathrm{t}}<2.2$ & 38.0 \\
\hline I-type & 23 & $630-965$ & $2.2 \leq \mathrm{L} / \mathrm{W}_{\mathrm{Lt}-\mathrm{t}} \leq 5.2$ & 26.0 \\
\hline Total & $\mathbf{8 9}$ & & & 100.0 \\
\hline
\end{tabular}

a

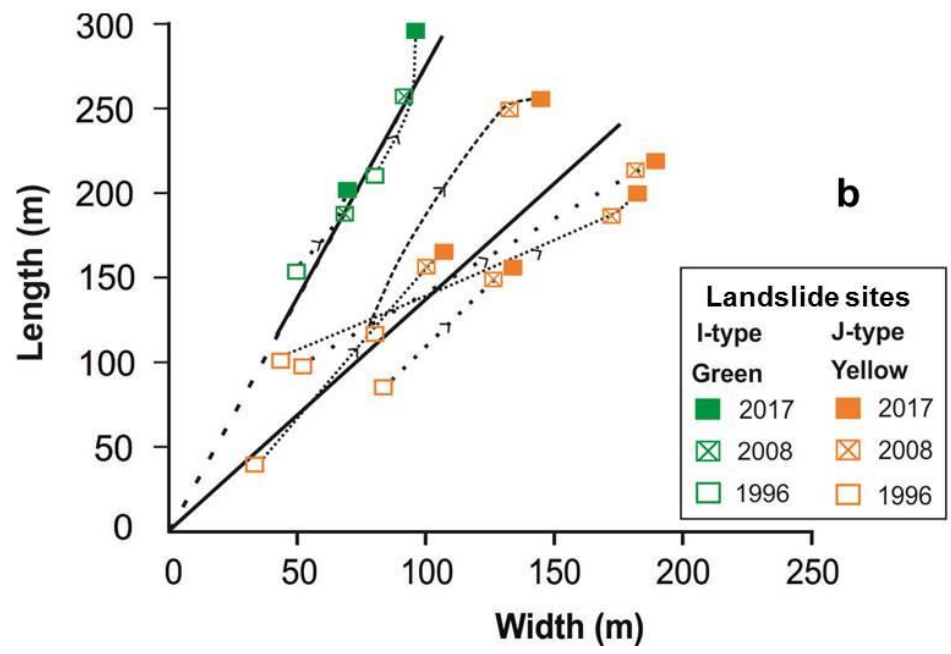

Figure 7. (a) Table of aspect ratios of landslide types at Skolis Mtn; (b) Plot showing the temporal increase of the length or the width of the I- and J-type slides at Santomerion village. 


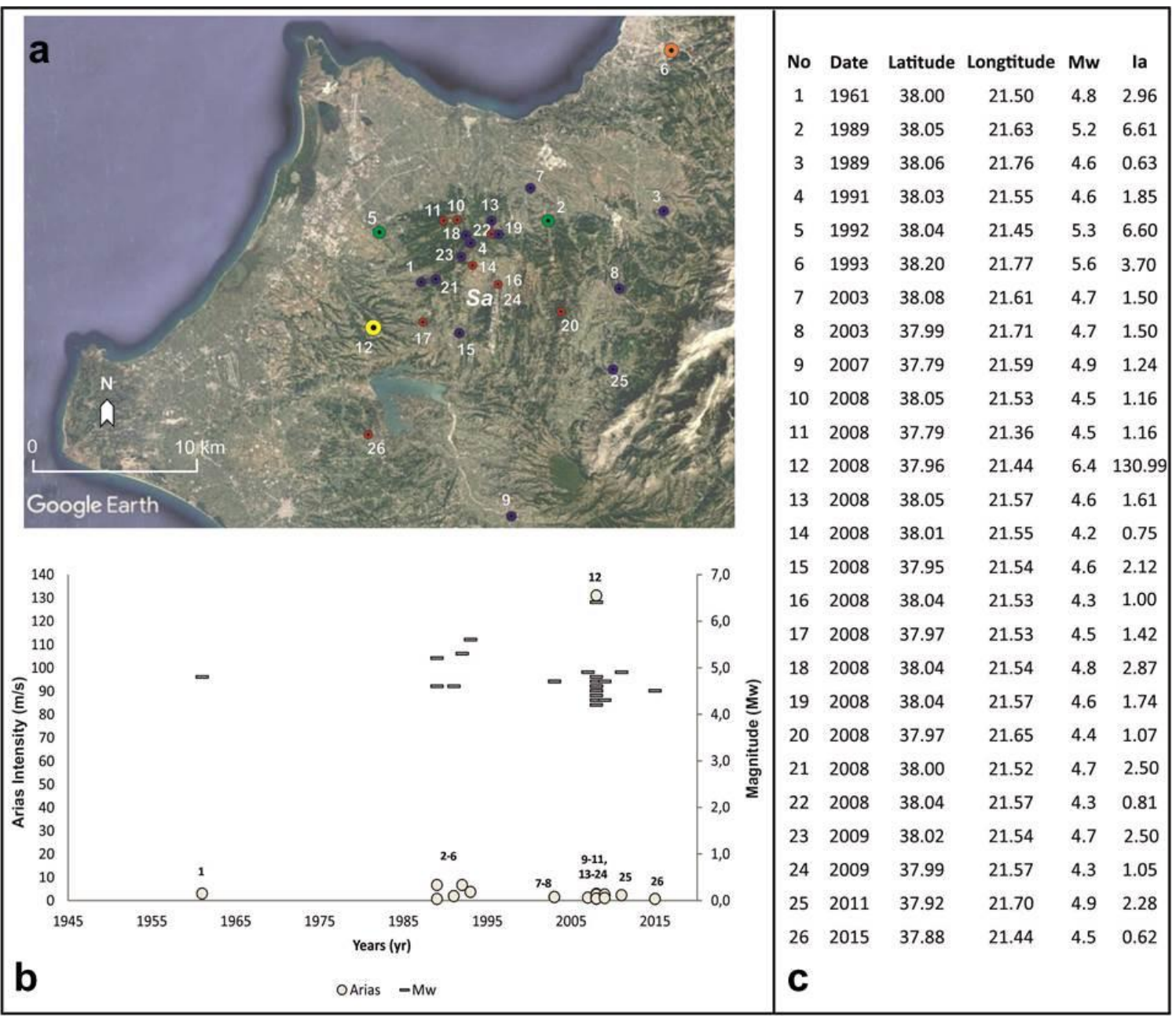

Figure 8. (a) Map of epicenter distribution in the Skolis Mtn area for the period. The map is extracted from Figure 4. $0 \leq \mathrm{Mw} \leq 4.5$ events, the blue show the epicenters of $4.6 \leq \mathrm{Mw} \leq 5.0$ events, the green show the epicenters of the $5.1 \leq \mathrm{Mw} \leq 5.5$ events, the orange shows the epicenters of $5.6 \leq \mathrm{Mw} \leq 6.0$ events, and the yellow dots show the epicenters of $6.1 \leq \mathrm{Mw} \leq 6.5$ events. The plotted events affected the landslide distribution and contributed to their evolution as deduced by the Arias intensity calculation. Sa: Santomerion village; (b) Diagram of Arias intensities, provided by Equation (1) and seismic magnitudes that affected Skolis area from 1945-2017. (c) The table presents the critical events that affected the studied area. The last years of 2016-2017 show no seismicity.

\subsection{Estimation of Arias Intensity for Historical Events}

The Arias intensity is a measure of the total seismic energy that is ground absorbed and is based on instrumental records. A large number of empirical attenuation relationships have been tested and evaluated in recent years with the one developed by Danciu and Tselentis [54] to incorporate data primarily from the Greek territory. Events that appeared in Figure 8 are those suggested as capable of causing slope failures in the Skolis Mtn following the Arias intensity $\left(I_{a}\right)$ according to the Danciu and Tselentis [54] equation:

$$
\log I_{a}=a+b M-c \log \left(\sqrt{R^{2}+h^{2}}\right)+e S+f F+\varepsilon,
$$

where $\mathrm{M}$ is the magnitude; $\mathrm{R}$ is the epicentral distance from the event to the location; $\mathrm{h}$ is the "fictitious" focal depth; and the variables $S$ and F refer to the site classification and fault mechanism, respectively. The soil condition coefficients, e and $f$, are considered independent of magnitude, distance, and level of ground shaking. The model error is given by $\varepsilon$ and is normally distributed with zero mean. 
In order to evaluate the range of the earthquake magnitudes that possibly trigger landslides in the Skolis Mtn, we estimated the critical epicentral distance according to Papadopoulos and Plessa [55], which is defined by the equation:

$$
\log \left(R_{e}\right)=-2.98+0.75 M_{s} \text { for } M_{s} \geq 5.3,
$$

where the equation uses seismic magnitudes (M) and their distance of the Skolis Mtn (R).

The calculated values of the $I_{a}$ are outlined in the diagram of Figure 8 for the events in the NW Peloponnese.

Out of the 86 recorded seismic events during the 72 year inventory period, 26 events with magnitudes above 4.2 indicate that $I_{a}$ possibly correlated with the Skolis Mtn landslides (Figure 8). These earthquakes are located mainly to the north and west of the mountain. In Figures $4 \mathrm{~d}$ and 8 , seismicity pre-dates the increase in the number of landslides during the three periods. In the same period, the climatic data and rock tectonics were stable; the appearance and the aspect ratio development of the landslides are related to the earthquakes in the table of Figure 8. In detail, this progressive evolution of landslide sites is plotted in Figures $4 \mathrm{~d}$ and 5.

\subsection{Statistical Analysis of Landslide Area Evolution}

The affected area is about $293.000 \mathrm{~m}^{2}$, occupying $7.5 \%$ of the total area (Table 3). The statistical analysis of landslide spatial and temporal distribution for the last interval indicates a minimum, mean, and maximum value of affected area of 148,3329 , and $23,828 \mathrm{~m}^{2}$, respectively (Table 3). Furthermore, the analysis of data on the extent of area affected by long-term seismicity in the Skolis Mtn indicates that the 1989, 1992, and 1993 earthquake activity resulted in a 49\% increase of the maximum landslide area, while the minimum area remained stable (Table 3). In contrast, the 2008 earthquake activity showed that $118 \%$ of the minimum and $112 \%$ of the maximum landslide area has been increased (Table 3). Although the increase of the seismically induced larger landslides is mapped (Figure 5), the stability denotes that the 1989, 1992, and 1993 earthquake activity have not affected the smaller landslides, in contrast to the 2008 earthquake (Figures 5 and 8 and Table 3). Therefore, the size of smaller landslides depends primarily on the seismic magnitude for $\mathrm{Mw} \geq 5.6$, and secondarily, on the maximum distance from the epicenter. Moreover, statistics of landslide distribution (Figures $4 \mathrm{~d}$ and 9 ) including correlation of two landslide proxies are described below (Figures 9b,c and 10).

The charts in Figure $9 \mathrm{c}$ represent a plot of the cumulative number of landslide area relationship for earthquake-induced landslides from 1945 to 2017 in the Skolis Mtn. The up to now knowledge of the effects of independent variables on dependent variables can help us understand the evolution of the spatial distribution of landslides during a seismic event. Therefore, we created a scatter chart showing the relationship between $\mathrm{x}$ and $\mathrm{y}$ (independent and dependent variable) for the original data using a power regression model (Figure 9c). This model is based on the following equation:

$$
y=\alpha x^{\beta},
$$

Thus, our dataset yields a power curve with the relationship:

$$
y=0.0057 x^{0.9136},
$$

with $R^{2}=0.85$. Since the exponent is so close to one, the curve is almost a straight line. 


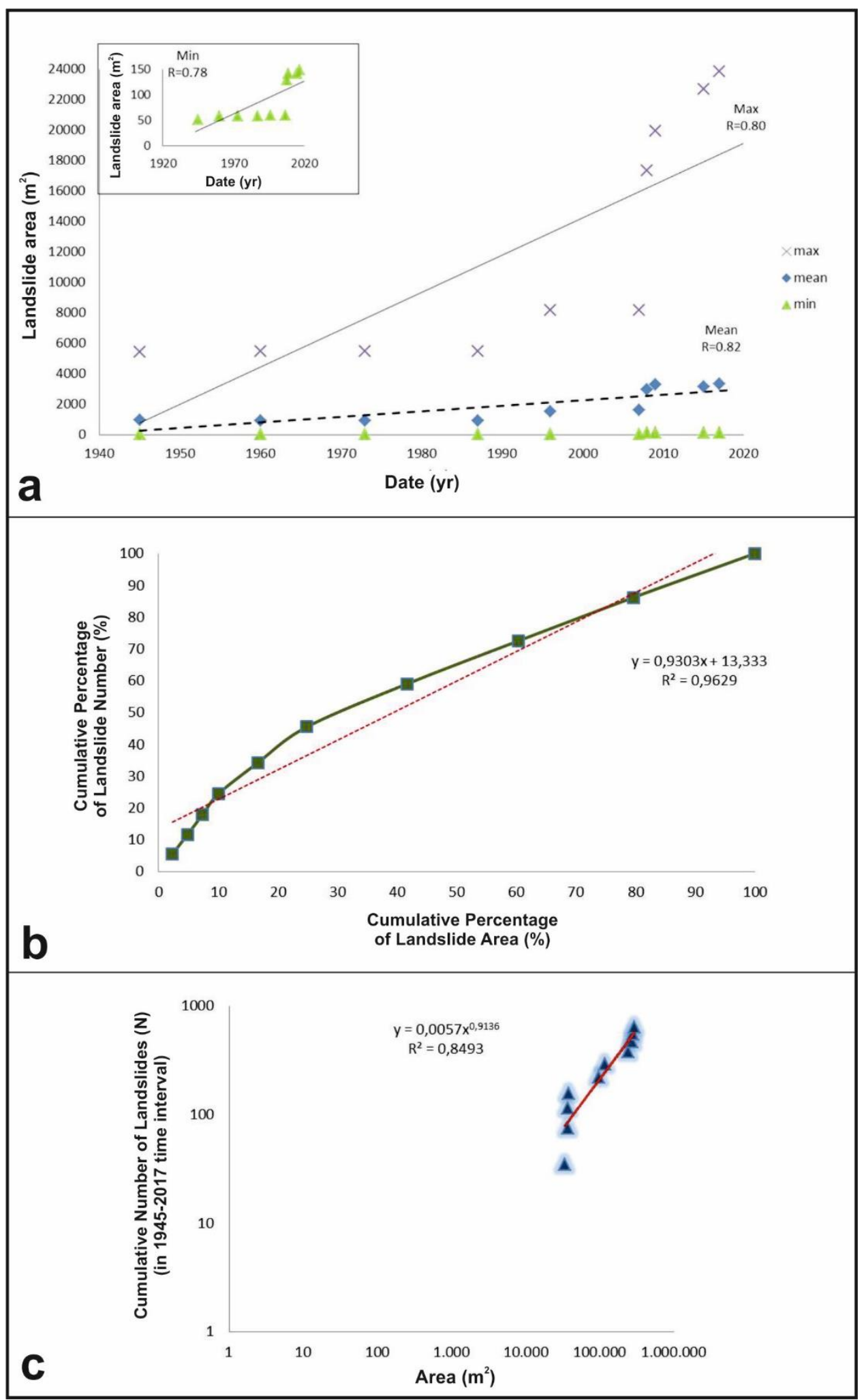

Figure 9. (a) Correlation between dates, minimum, maximum, and mean area of studied landslides from 1945 to 2017. The insert shows the minimum area distribution in a larger scale; (b) The cumulative percentage of landslide number is plotted against the cumulative percentage of landslide area; (c) Regression analysis using the log-log scale. The coefficient of determination, $\mathrm{R}^{2}$, denotes the strength of the linear association between the cumulative number of landslides and area. 


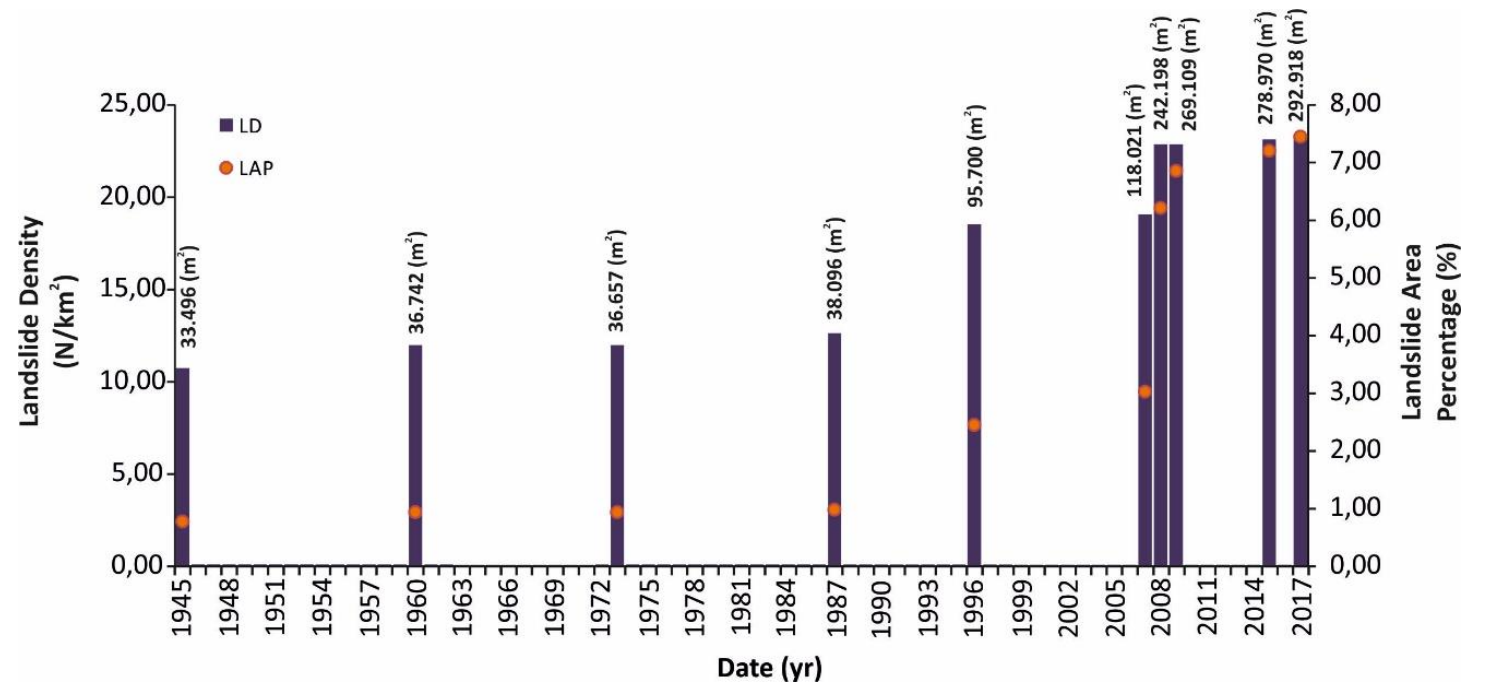

Figure 10. Landslide density and landslide area percentage versus date. The columns represent the landslide density and the dots the landslide area percentage. The labels on the columns indicate the extent of the affected area.

In agreement with the aforementioned results, there is a significant positive relationship between the number of landslides and the affected area, $R=0.92\left(R^{2}=0.85\right)$ in this regression analysis. The $P$-value was 0.000148 , less than 0.001 , which indicates that the correlation between cumulative number of landslides and affected area is statistically highly significant. It constitutes a continuous process of causal reasoning and hence the curve in the regression analysis is almost a straight line (Figure 9c). Likewise, Figure 9b shows an accumulative curve of landslide occurrences. The slope $\mathrm{b}=0.9303$ was positive, indicating that as the percentage of landslide number increases, the percentage of landslide area also increases. In this regression analysis, the $P$-value was 0.00000052 (or $5.2 \times 10^{-7}$ ), less than 0.001 , which indicates that the correlation coefficient was statistically highly significant. The correlation of determination $\mathrm{R}^{2}=0.96$ can be considered as excellent, suggesting that the model is valid.

The statistical analysis of landslide occurrences is described in Table 2 by using three indices: LD, LAP, and LF. Most landslide sites in the Skolis Mtn exhibit a critical behavior, which is reflected by a continuous increase in their number and size over the 72 year period of record, indicating a LAP of $7.51 \%$, a LD of 22.82 landslides per square kilometer, and a long-term average LF of 7.3 landslides $\cdot \mathrm{km}^{-2} \cdot \mathrm{yr}^{-1}$. Calculation of the latter three parameters is advantageous in the Skolis case and in similar cases of seismically active areas.

The diagram in the following figure (Figure 10) depicts correlations between landslide occurrences and the chronological dates of landslides and affected area (Figure 10). Particularly, Figure 10 shows the percentage of the area occupied by a number of landslides relative to acquisition date. This plot shows a stability from 1945 to 1987, from 1996 to 2007 (see Section 5), and from 2010 to 2017, which corresponds to the period of seismic quiescence. Contrariwise, from the 1987 to 1996 and 2007 to 2009 seismic periods, we can notice that the LAP value (dots) demonstrates a more significant increase than the $\mathrm{LD}$ value (bars). The latter approves the considerable increase of the landslide mass, in terms of inflation and enlargement, which affects the whole landslide body. Therefore, the reactivated landslides of the abovementioned seismic periods, not only occurred within the pre-existing landslide masses, but have also been fully mobilized by significantly increasing their size (Figures 5 and 6 and Table 3). Thus, apart from the appearance of new landslides, there was an even higher increase of landslide area.

More specifically, Figure 10 and the curves in Figure $9 \mathrm{~b}, \mathrm{c}$ indicate that apart from the appearance of new landslides, there was an even higher increase of landslide area. The reasons for this fact are: (i) the reactivated landslides occurred within pre-existing landslide masses, increasing their size; (ii) the larger landslides occurred at higher elevations, where most instability phenomena take place; and (iii) the 
majority of the earthquake magnitudes in the Skolis Mtn territory affected the larger landslides more than the smaller ones, as described earlier in this section (Table 3).

\subsection{Qualitative Analysis}

Post-Earthquake Landslide Morphological Evolution

The post-earthquake results indicate that the deposition area corresponds to the accumulation zone forming new taluses. This process is mainly characterized by an increase in (i) width (inflation) that strongly affects $\Delta$-shaped landslides, and (ii) the main landslide body [52] shows an increase in length (enlargement) that affects primarily the I- and J-shaped landslides. Apart from the inflation that occurred in the deposition area of all landslides, an enlargement in most of the landslides took place. It is worth mentioning that the enlargement is considered as the factor that contributes more than the inflation to the local vulnerability due to the proximity of the Santomerion and Portes villages to Iand J-landslide types (Figures 5 and 6). The enlargement is the main process increasing the risk in the Skolis communities with the increase of the I-, J-, and $\Delta$-shaped landslides during the earthquake.

The rock fall dimension data were evaluated using ArcGIS. Hence, the estimated minimum and maximum lengths of the I-, J-, and $\Delta$-shaped landslides were 40, 18, and $10 \mathrm{~m}$ and 395, 342, and $203 \mathrm{~m}$, respectively.

\section{Discussion}

Landslide inventory maps are the key component of a landslide hazard or risk assessment, particularly when they are comprised of seismic catalogs, continuous imagery, acquisition dates, and accurate estimates of affected area (volume, area).

A multi-temporal landslide inventory of earthquake induced landslides led to the understanding of the earthquake imposed hazards and to the development of models and methods for hazard mapping and evaluation $[7,18,56]$. The information we provide with this method can be used as an advantageous tool in hazard or risk assessment. In general, the examination of landslide behavior is a reliable solution to estimate the future evolution and to predict its mitigation provided us with knowledge to prevent forthcoming disasters. Since we meet the landslide inventory and mapping criteria, described by Harp et al. [17], the inventory will be of sufficient accuracy and completeness to accommodate seismic landslide hazard analysis. In order to make a reliable map that predicts the landslide hazard and risk in a certain area, it is crucial to have insights in the spatial and temporal frequency of landslides, and therefore each landslide hazard or risk study should start by making a landslide inventory that is as complete as possible in both space and time [5,57-59].

\subsection{Reach Angle}

The local tectonic grain in the study area, which is mainly represented by an anticline and Skolis Thrust Fault, has formed and shaped the characteristic natural steep slopes of Skolis Mtn [29]. In slopes covered with scree deposits, debris failures are expected to occur on slope angles over $30^{\circ}$ [60]. Dai and Lee [61] carried out a statistical analysis of landslide height-length (H/L) ratios of 2135 landslides in Lantau Island, Hong Kong, providing the relationship of landslide $H$ and $L$ as $H=0.524 \mathrm{~L}+1.257, \mathrm{R}^{2}=0.87$, and the average reach angle of $27.6^{\circ}$ (arc tangent 0.524 ). In addition, Qi et al. [62] performed an analysis of landslide height-length ratios of 66 long runout rock avalanches from the 2008 Wenchuan earthquake and obtained a relationship that is $\mathrm{H}=0.2638 \mathrm{~L}+212.4$, with $\mathrm{R}^{2}=0.6716$ and average reach angle of $14.7^{\circ}$. Similarly, $\mathrm{Xu}$ et al. [63] obtained the relationship $\mathrm{H}=0.595 \mathrm{~L}$, with $\mathrm{R}^{2}=0.6972$ and average reach angle of $30.7^{\circ}$, based on 453 landslides from the 2010 Haiti earthquake. Thus, we used the height $(\mathrm{H})$ and length $(\mathrm{L})$ of 89 landslides from the 2008 Movri earthquake to yield the regression relationship: $\mathrm{H}=0.6645 \mathrm{~L}+3.7235$, with a coefficient of determination of $R^{2}=0.9209$ (Figure 11). This means that the average reach angle is about $33.6^{\circ}$, which is close to the arc tangent value of the friction coefficient of most natural rock types 
$\left(\approx 30^{\circ}\right)$, according to Corominas [64]. Figure 11 shows the strong positive correlation (0.92) between the horizontal length $(\mathrm{L})$ and change in elevation/height $(\mathrm{H})$ using a scatterplot. Figure 11 shows the fitting lines of the $\mathrm{H} / \mathrm{L}$ ratios using data from previous studies. The comparison between the aforementioned studies and the current one indicates that the reach angles were in the range of $27.6^{\circ}$ to $33.6^{\circ}$. Nevertheless, we noticed the small reach angle in the results of Qi et al. [62], which can be explained by the fact that the larger the landslide, the smaller the angle of reach obtained $[60,64]$, as the rapid-moving avalanches travel a long distance.

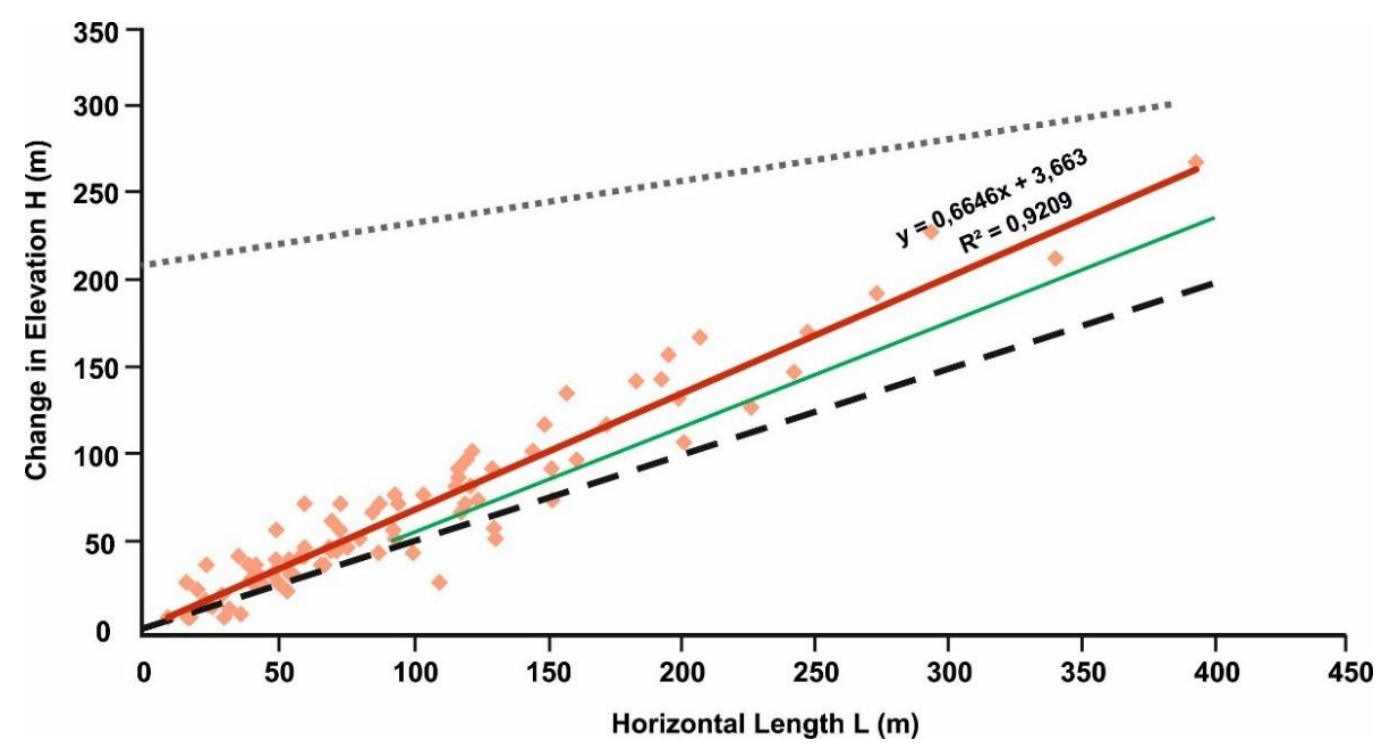

Figure 11. Relationship between horizontal length (L) and change in elevation/height (H): Black dashed line: Dai and Lee [60]; Green line: Xu et al. [62]; Red bold line: linear fit that corresponds to the present event-based landslide inventory; Grey dashed line: Qi et al. [62].

\subsection{Aspect Ratio}

Seismicity is undoubtedly a significant landslide triggering factor like the case in Santa Susana during the $\mathrm{Mw}=6.7$ Northridge earthquake. According to Parise and Jibson [65], single landslide areas ranged from $23 \mathrm{~m}^{2}$ to more than $25.000 \mathrm{~m}^{2}$ and averaged $1.520 \mathrm{~m}^{2}$. Similarly, in the Skolis Mtn, the landslide areas ranged from $50 \mathrm{~m}^{2}$ to $23.830 \mathrm{~m}^{2}$ and averaged $3.328 \mathrm{~m}^{2}$. Furthermore, the estimated aspect ratios had a mean ratio of 2.6, while in the case of Skolis Mtn, the mean aspect ratio was 1.8. While the elevations of the Skolis and Santa Susana Mountains range from 350 to $970 \mathrm{~m}$ and 270 to $950 \mathrm{~m}$, respectively, there was a difference between their average aspect ratios. We assumed that the difference was due to the fact that the Skolis Mtn area is represented by landslides while Northridge mainly by single landslides showing long runout distances. This factor determined the shape (extent of elongation) and the enlargement of landslides.

As the Skolis Mtn is located in an area prone to strong earthquakes, the need to define landslide hazard zones is imperative. Monitoring of landslide evolution provides insights into: (i) the development of unstable rock slopes in relation to their proximity to residential areas, showing the landslide potential to exceed the moderate-risk zone and reach the high-risk zone; and (ii) the maximum runout distance at $27^{\circ}$. The latter indicates that some villages in the area located between $27^{\circ}$ and $33.6^{\circ}$, within the zone of high to moderate-risk (Figure 12). 

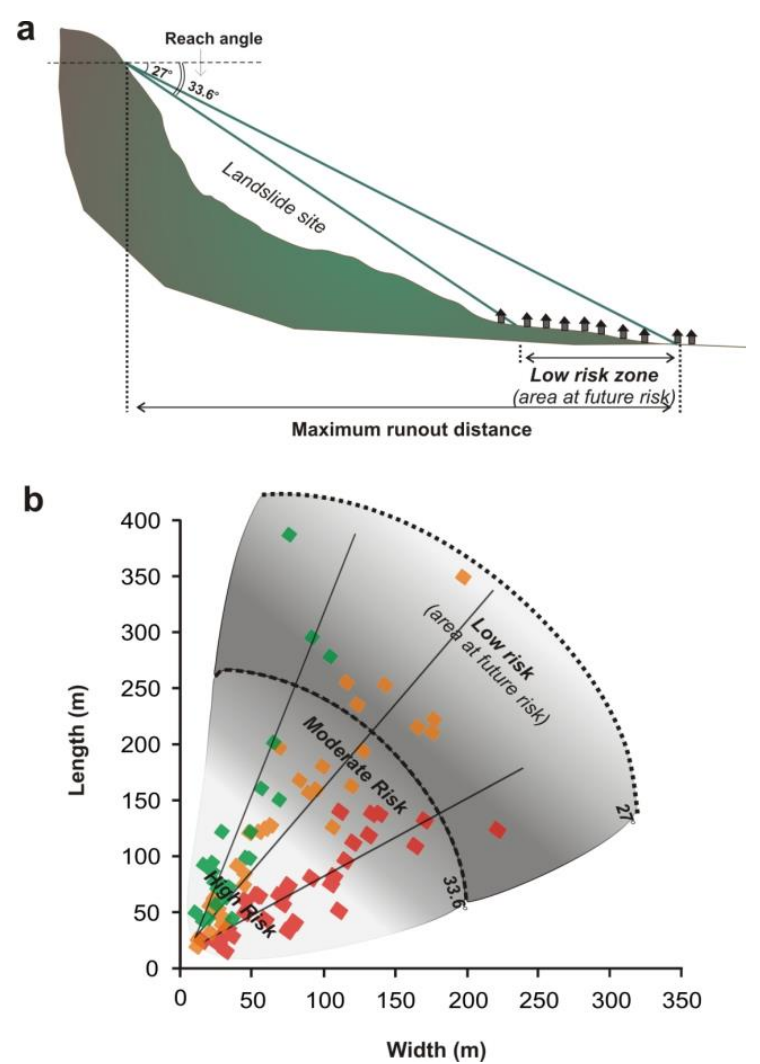

Figure 12. (a) Maximum runout distance of landslides: the reach angle of $33.6^{\circ}$ indicates the slope angle on which most earthquake-induced landslides in this area generally occur (see Section 7.1 for additional explanation). (b) Landslide hazard zonation of the Skolis Mtn. The rate of risk corresponds to the proximity to residential areas.

\subsection{Recurrence Period and Rate of Length}

After a detailed estimation of the length of each landslide site, we selected fourteen of them due to their proximity to Santomerion village (Figure 13). The rate of length was defined as $\mathrm{RL}=\Delta \mathrm{L} / \Delta \mathrm{t}$, where $\Delta \mathrm{L}$ is the difference between the length of the last and the first observation and $\Delta \mathrm{t}$ is the time interval and is expressed in meters per year $\left(\mathrm{m} \mathrm{yr}^{-1}\right)$. Thus, fourteen rates of length were calculated for the corresponding landslide sites in the Santomerion area, between the oldest (acquisition) and the most recent date (1945-2017). The RL of the particular landslide sites ranged from 1.1 to $4.8 \mathrm{~m} \mathrm{yr}^{-1}$ with a mean of $2.3 \mathrm{~m} \mathrm{yr}^{-1}$ (Figure 13).

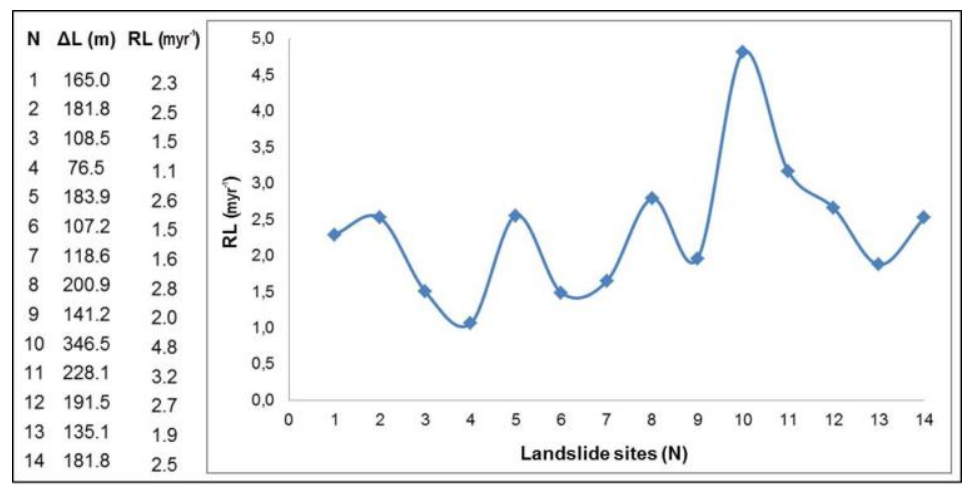

Figure 13. The table and the chart illustrate the results of estimated RL for each landslide site in the Santomerion area from 1945-2017. 
The evaluation of our multi-temporal inventory indicates a periodic recurrence of earthquakeinduced landslides after critical events, thus suggesting a length-predictable earthquake recurrence model. According to this model, it is considered that there is no significant increase in periods of seismic quiescence. The increase takes place when an earthquake of critical magnitude occurs; each seismic period will end when the next critical event occurs at a random time $t_{x}(\mathrm{yr})$.

Eventually, in order to enhance and improve our previous data, we created a landslide inventory that also encompassed quantitative and qualitative data. The authors focused on the quantitative and qualitative analysis in conjunction with the multi-temporal, spatial, and statistical analysis aimed at presenting the results to potential users. Further developments are the use of the Skolis model: (i) in correlation with other landslide prone anticlines with similar characteristics; (ii) to determine the probability of potential landslide occurrence in mountainous areas; and (iii) to construct probabilistic prediction models.

\subsection{Hazard Map}

This analysis can be summarized in the compilation of a large-scale landslide hazard map (Figure 14). This map involves the probability of landslide enlargement based on (a) the shape of landslide at different time intervals, and (b) calculation of the assessed landslide annual evolution rate.

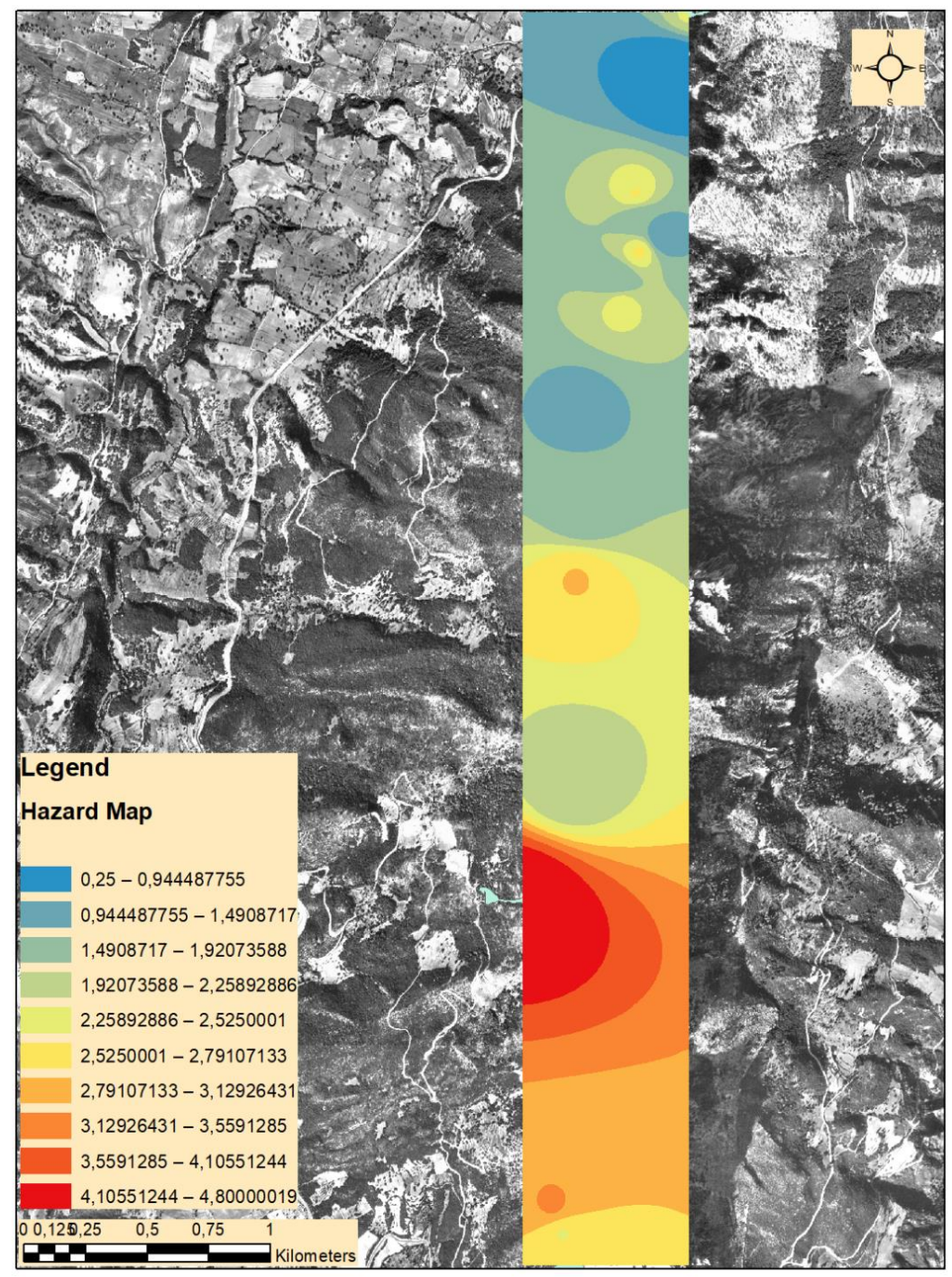

Figure 14. Hazard map of the area between Portes in the south and Santomerion villages in the north. 
According to their shape (I, J, and $\Delta$ ), the landslides are classified in three categories, rated from 1 to 3. The landslides that form a $\Delta$-shape are characterized as less dangerous and rated with value 1 , while the I-shaped landslides are the most dangerous, rated with value 3 . The enlargement rate of these landslides range between 0.5 and $4.8 \mathrm{~m} / \mathrm{yr}$. As quantitative hazard and risk acceptance criteria are usually expressed in annual terms, the annual evolution rate of each landslide measured in $\mathrm{m} \mathrm{yr}^{-1}$ is used in order to classify the landslide hazard. The evolution rate is classified in four categories from 1 to 4 . The enumeration of the two factors (landslide shape and annual evolution rate) is presented in Table 4. Spatial interpolation algorithm has been used in order to produce the landslide hazard map (Figure 14).

Table 4. Weight of the landslide hazard in the study area. Green color represents the low hazard, yellow and light orange represent moderate hazard and red and dark red color high hazard.

\begin{tabular}{ccccc}
\hline Rate of Increase/Type & $\mathbf{0 - 1 . 5} \mathbf{~ m ~ y r}^{-\mathbf{1}}$ & $\mathbf{1 . 5 - 3} \mathbf{~ m ~ y r}^{-\mathbf{1}}$ & $\mathbf{3 - 4 . 5} \mathbf{~ m ~ y r}^{\mathbf{- 1}}$ & $\mathbf{> 4 . 5} \mathbf{~ m ~ y r}^{\mathbf{- 1}}$ \\
\hline$\Delta$ & 1 & 2 & 3 & 4 \\
\hline $\mathrm{J}$ & 2 & 4 & 6 & 8 \\
\hline $\mathrm{I}$ & 3 & 6 & 9 & 12 \\
\hline
\end{tabular}

Rate of increase per year: (1) $=0-1.5 \mathrm{~m} \mathrm{yr}^{-1},(2)=1.5-3 \mathrm{~m} \mathrm{yr}^{-1},(3)=3-4.5 \mathrm{~m} \mathrm{yr}^{-1},(4)=>4.5 \mathrm{~m} \mathrm{yr}^{-1}$.

\section{Conclusions}

In this work, landslide events that have occurred in the Skolis Mtn were compiled as an event-based landslide inventory comparing the pre-event and post-event landslide inventory. The comparison between multi-temporal data displays corresponding to different periods makes it possible to determine the enlargement and inflation of landslide sites. Geomorphological and seismic analysis with data processing in a GIS environment allowed us to define the spatial and temporal distribution and the activity of landslides on the west slopes of the Skolis Mtn. Our results are summarized as follows:

1. The existence of former landslides constitutes the determinant factor. The reactivated landslides not only occurred within pre-existing landslide masses, but they have also been fully mobilized by significantly increasing their size up to three times.

2. Although the proportional increase of the larger landslides resulting from the Arias intensities is expected, the increase of the smaller landslides is subject to certain limitations such as seismic magnitude, $M w \geq 5.6$ and distance from the epicenter, $R=11 \mathrm{~km}$. The outcome of this process is a landslide inventory map through the GIS environment showing the size and distribution of landslides triggered by a $\mathrm{Mw}=6.4$ earthquake (Figures 5 and 14 ).

3. Increased percentages of LAP and LD negatively affect the slope stability, especially in the last two decades (Table 2). The coincidence of the high LAP and LD with moderate to strong earthquakes also suggests potential slope failure in an area prone to landslide phenomena.

4. The calculation of the rate of length is quite crucial. High RL values along with seismic activity can be used for the evaluation of landslide hazard assessment of inhabited or unstable areas.

5. The proposed model of the inventory analysis is coherent with the interpretation of the temporal and spatial distribution showing high periods of stability and short periods of rapid length evolution during short periods of seismicity. Our method is interesting both for (i) the landslide mapping and evolution in mountainous areas throughout time, and (ii) the significance of long term landslide monitoring as a base for the compilation of a landslide inventory and hazard analysis and assessment. 
Author Contributions: Conceptualization, Aspasia Litoseliti and Ioannis K. Koukouvelas; Methodology, Aspasia Litoseliti and Ioannis K. Koukouvelas; Software, Aspasia Litoseliti and Konstantinos G. Nikolakopoulos; Field Work, Aspasia Litoseliti, Ioannis K. Koukouvelas, Konstantinos G. Nikolakopoulos, and Vasiliki Zygouri; Data Curation, Aspasia Litoseliti, Ioannis K. Koukouvelas, and Konstantinos G. Nikolakopoulos; Writing-Original Draft Preparation, Aspasia Litoseliti; Writing-Review and Editing, Aspasia Litoseliti, Ioannis K. Koukouvelas, Konstantinos G. Nikolakopoulos, and Vasiliki Zygouri. All authors have read and agreed to the published version of the manuscript.

Funding: This research received no external funding.

Acknowledgments: The authors would like to express their gratitude to the three anonymous reviewers for their constructive and helpful comments that substantially improved the manuscript. This work was partly supported by grant E078 from the Research Committee of the University of Patras to IK and VZ (Program K. Karatheodori). In addition, we acknowledge the careful English language editing by George Kostiras, Professor of English Literature.

Conflicts of Interest: The authors declare no conflicts of interest.

\section{References}

1. Cruden, D.M. A Simple Definition of a Landslide. Bull. Int. Assoc. Eng. Geol. 1991, 43, 27-29. [CrossRef]

2. Fell, R.; Whitt, G.; Miner, A.; Flentje, P.N. Guidelines for landslide susceptibility, hazard and risk zoning for land use planning. Aust. Geomech. J. 2007, 42, 13-36.

3. Guzzetti, F.; Mondini, A.C.; Cardinali, M.; Fiorucci, F.; Santangelo, M.; Chang, K.T. Landslide inventory maps: New tools for an old problem. Earth Sci. Rev. 2012, 112, 42-66. [CrossRef]

4. Van Westen, C.J.; Van Asch, T.W.J.; Soeters, R. Landslide hazard and risk zonation-why is it still so difficult? Bull. Eng. Geol. Environ. 2006, 65, 167-184. [CrossRef]

5. Van Westen, C.J.; Castellanos, E.A.; Kuriakose, S.L. Spatial data for landslide susceptibility, hazards and vulnerability assessment: An overview. Eng. Geol. 2008, 102, 112-131. [CrossRef]

6. $\mathrm{Xu}, \mathrm{C}$. Preparation of earthquake-triggered landslide inventory maps using remote sensing and GIS technologies: Principles and case studies. Geosci. Front. 2015, 6, 825-836. [CrossRef]

7. Keefer, D.K. Investigating landslides caused by earthquakes-A historical review. Surv. Geophys. 2002, 23, 473-510. [CrossRef]

8. Guzzetti, F.; Reichenbach, P.; Cardinali, M.; Galli, M.; Ardizzone, F. Probabilistic landslide hazard assessment at the basin scale. Geomorphology 2005, 72, 272-299. [CrossRef]

9. Keefer, D. Landslides caused by earthquakes. Geol. Soc. Am. Bull. 1984, 95, 406-421. [CrossRef]

10. Wieczorek, G.F. Preparing a detailed landslide-inventory map for hazard evaluation and reduction. Bull. Int. Assoc. Eng. Geol. 1984, 21, 337-342. [CrossRef]

11. Guzzetti, F.; Cardinali, M. Landslide inventory map of the Umbria region, Central Italy. In Proceedings of the ALPS 90 6th International Conference and Field Workshop on Landslides, Milan, Italy, 12 September 1990; pp. 273-284.

12. Soeters, R.; Van Westen, C.J. Slope instability recognition, analysis, and zonation. In Landslides, Investigation and Mitigation; Turner, A.K., Schuster, R.L., Eds.; National Academy Press: Washington, DC, USA, 1996; pp. 129-177, ISBN 0-309-06151-2.

13. Rodríguez, C.E.; Bommer, J.J.; Chandler, R.J. Earthquake-induced landslides: 1980-1997. Soil Dyn. Earthq. Eng. 1999, 18, 325-346. [CrossRef]

14. Harp, E.L.; Jibson, R.L. Inventory of landslides triggered by the 1994 Northridge, California earthquake. USGS Open-File Rep. 1995, 95-213. [CrossRef]

15. Harp, E.L.; Jibson, R.L. Landslides triggered by the 1994 Northridge, California earthquake. Bull. Seismol. Soc. Am. 1996, 86, 319-332.

16. Keefer, D.K. Statistical analysis of an earthquake-induced landslide distribution-the 1989 Loma Prieta, California event. Eng. Geol. 2000, 58, 231-249. [CrossRef]

17. Harp, E.L.; Keefer, D.K.; Sato, H.P.; Yagi, H. Landslide inventories: The essential part of seismic landslide hazard analyses. Eng. Geol. 2011, 122, 9-21. [CrossRef]

18. Dai, F.C.; Xu, C.; Yao, X.; Xu, L.; Tu, X.B.; Gong, Q.M. Spatial distribution of landslides triggered by the 2008 Ms 8.0 Wenchuan earthquake, China. J. Asian Earth Sci. 2011, 40, 883-895. [CrossRef] 
19. Guzzetti, F.; Reichenbach, P.; Cardinali, M.; Ardizzone, F.; Galli, M. Impact of landslides in the Umbria Region, Central Italy. Nat. Hazards Earth Syst. Sci. 2003, 3, 469-486. [CrossRef]

20. Gorum, T.; Fan, X.; van Westen, C.J.; Huang, R.Q.; Xu, Q.; Tang, C.; Wang, G. Distribution pattern of earthquake-induced landslides triggered by the 12 May 2008 Wenchuan earthquake. Geomorphology 2011, 133, 152-167. [CrossRef]

21. Malamud, B.D.; Turcotte, D.L.; Guzzetti, F.; Reichenbach, P. Landslide inventories and their statistical properties. Earth Surf. Process. Landf. 2004, 29, 687-711. [CrossRef]

22. Cardinali, M.; Reichenbach, P.; Guzzetti, F.; Ardizzone, F.; Antonini, G.; Galli, M.; Cacciano, M.; Castellani, M.; Salvati, P. A geomorphological approach to estimate landslide hazard and risk in urban and rural areas in Umbria, central Italy. Nat. Hazards Earth Syst. Sci. 2002, 2, 57-72. [CrossRef]

23. Carrara, A.; Crosta, G.B.; Frattini, P. Geomorphological and historical data in assessing landslide hazard. Earth Surf. Process. Landf. 2003, 28, 1125-1142. [CrossRef]

24. Guzzetti, F.; Galli, M.; Reichenbach, P.; Ardizzone, F.; Cardinali, M. Landslide hazard assessment in the Collazzone area, Umbria, central Italy. Nat. Hazards Earth Syst. Sci. 2006, 6, 115-131. [CrossRef]

25. Tian, Y.; Xu, C.; Chen, J.; Zhou, Q.; Shen, L. Geometrical characteristics of earthquake-induced landslides and correlations with control factors: A case study of the 2013 Minxian, Gansu, China, Mw 5.9 event. Landslides 2017, 14, 1915-1927. [CrossRef]

26. Arias, A. Arias, A. A measure of Earthquake Intensity. In Seismic Design of Nuclear Power Plants; Hansen, R.J., Ed.; The MIT Press: Cambridge, MA, USA, 1970; pp. 438-483.

27. Keefer, D.K.; Wilson, R.C. Predicting earthquake-induced landslides, with emphasis on arid and semi-arid environments. In Landslides in a Semi-Arid Environment with Emphasis on the Inland Valleys of Southern California; Sadler, P.M., Morton, D.M., Eds.; Inland Geological Society of Southern California Publications: Riverside, CA, USA, 1989; Volume 2, pp. 118-149.

28. Harp, E.L.; Wilson, R.C. Shaking intensity thresholds for rock falls and slides: Evidence from 1987 Whittier Narrows and Superstition Hills earthquake strong-motion records. Bull. Seismol. Soc. Am. 1995, 85, 1739-1757.

29. Koukouvelas, I.; Litoseliti, A.; Nikolakopoulos, K.; Zygouri, V. Earthquake triggered rock falls and their role in the development of a rock slope: The case of Skolis Mountain, Greece. Eng. Geol. 2015, 191, 71-85. [CrossRef]

30. Serpetsidaki, A.; Elias, P.; Ilieva, M.; Bernard, P.; Briole, P.; Deschamps, A.; Lambotte, S.; Lyon-Caen, H.; Sokos, E.; Tselentis, G.-A. New constraints from seismology and geodesy on the Mw $=6.42008$ Movri (Greece) earthquake: Evidence for a growing strike-slip fault system. Geophys. J. Int. 2014, 198, 1373-1386. [CrossRef]

31. Roumelioti, Z.; Theodoulidis, N.; Bouchon, M. Constraints on the location of the 2008, MW 6.4 Achaia-Ilia earthquake fault from strong motion data. Bull. Geol. Soc. Gr. 2013, 47, 1231-1240. [CrossRef]

32. Koukouvelas, I.; Kokkalas, S.; Xypolias, P. Surface deformation during the Mw 6.4 (8 June 2008) Movri Mountain earthquake in the Peloponnese, and its implications for the seismotectonics of western Greece. Int. Geol. Rev. 2010, 52, 249-268. [CrossRef]

33. Koukis, G.; Ziourkas, C. Slope instability phenomena in Greece: A statistical analysis. Bull. Int. Assoc. Eng. Geol. 1991, 43, 47-60. [CrossRef]

34. Koukouvelas, I.; Mpresiakas, A.; Sokos, E.; Doutsos, T. The tectonic setting and earthquake hazards of the 1993 Pyrgos earthquake, Peloponnese, Greece. J. Geol. Soc. Lond. 1996, 153, 39-49. [CrossRef]

35. Gallousi, C.; Koukouvelas, I. Quantifying geomorphic evolution of earthquake-triggered landslides and their relation to active normal faults. An example from the Gulf of Corinth, Greece. Tectonophysics 2007, 440, 85-104. [CrossRef]

36. Keefer, D.K. Rock avalanches caused by earthquakes: Source characteristics. Science 1984, 223, $1288-1290$. [CrossRef] [PubMed]

37. Jibson, R.W.; Keefer, D.K. Analysis of the seismic origin of landslides: Examples from the New Madrid Seismic Zone. Bull. Seismol. Soc. Am. 1993, 105, 521-536. [CrossRef]

38. Kokkalas, S.; Kamberis, E.; Xypolias, P.; Sotiropoulos, S.; Koukouvelas, I. Coexistence of thin- and thick-skinned tectonics in Zakynthos area (Western Greece): Insights from seismic sections and regional seismicity. Tectonophysics 2013, 597-598, 73-84. [CrossRef] 
39. Chalkias, C.; Ferentinou, M.; Polykretis, C. GIS-Based Landslide Susceptibility Mapping on the Peloponnese Peninsula, Greece. Geosciences 2014, 4, 176-190. [CrossRef]

40. Litoseliti, A.; Koukouvelas, I.; Nikolakopoulos, K. Hazard due to earthquake-induced rock falls: The use of remote sensing data and field mapping in the case of Skolis Mountain, NW Peloponnese. Bull. Geol. Soc. Gr. 2014, 48, 4-26. [CrossRef]

41. Potere, D. Horizontal Positional Accuracy of Google Earth's High Resolution Imagery Archive. Sensors 2008, 8, 7973-7981. [CrossRef]

42. Benker, C.S.; Langford, R.P.; Pavlis, T.L. Positional accuracy of the Google Earth terrain model derived from stratigraphic unconformities in the Big Bend region, Texas, USA. Geocarto Int. 2011, 26, 291-303. [CrossRef]

43. Sato, H.P.; Harp, E.L. Interpretation of earthquake-induced landslides triggered by the 12 May 2008, M7.9 Wenchuan earthquake in the Beichuan area, Sichuan Province, China, using satellite imagery and Google Earth. Landslides 2009, 6, 153-159. [CrossRef]

44. Costanzo, D.; Rotigliano, E.; Irigaray, C.; Jimenez-Peralvarez, J.D.; Chacon, J. Factors selection in landslide susceptibility modelling on large scale following the gis matrix method: Application to the river Beiro basin (Spain). Nat. Hazards Earth Syst. Sci. 2012, 12, 327-340. [CrossRef]

45. Schicker, R.; Moon, V. Comparison of bivariate and multivariate statistical approaches in landslide susceptibility mapping at a regional scale. Geomorphology 2012, 161-162, 40-57. [CrossRef]

46. Hu, Q.; Wu, W.; Xia, T.; Yu, Q.; Yang, P.; Li, Z.; Song, Q. Exploring the Use of Google Earth Imagery and Object-Based Methods in Land Use/Cover Mapping. Remote Sens. 2013, 5, 6026-6042. [CrossRef]

47. Nikolakopoulos, K.; Dimitropoulos, G. Estimating the accuracy of vectors derived from open data. In Proceedings of the SPIE 10428, Earth Resources and Environmental Remote Sensing/GIS Applications VIII, 104280N, Warsaw, Poland, 5 October 2017. [CrossRef]

48. Evans, S.; Hungr, O. The assessment of rockfall hazard at the base of talus slopes. Can. Geotech. J. 1993, 30, 620-636. [CrossRef]

49. Hungr, O.; Leroueil, S.; Picarelli, L. The Varnes classification of landslide types, an update. Landslides 2014, 11, 167-194. [CrossRef]

50. Dorren, L.K.A. A review of rock fall mechanics and modelling approaches. Prog. Phys. Geogr. 2003, $27,69-87$. [CrossRef]

51. Micu, M.; Jurchescu, M.; Micu, D.; Zarea, R.; Zumpano, V.; Bălteanu, D. A morphogenetic insight into a multi-hazard analysis: Bâsca Mare landslide dam. Landslides 2014, 11, 1131-1139. [CrossRef]

52. IAEG Commission on Landslides. Suggested nomenclature for landslides. Bull. Int. Assoc. Eng. Geol. 1990, 41, 13-16. [CrossRef]

53. Niculita, M. Automatic landslide length and width estimation based on the geometric processing of the bounding box and the geomorphometric analysis of DEMs. Nat. Hazards Earth Syst. Sci. 2016, 16, 2021-2030. [CrossRef]

54. Danciu, L.; Tselentis, G.A. Engineering ground-motion parameters attenuation relationships for Greece. Bull. Seismol. Soc. Am. 2007, 97, 162-183. [CrossRef]

55. Papadopoulos, G.; Plessa, A. Magnitude-Distance relations for earthquake-induced landslides in Greece. Eng. Geol. 2000, 58, 251-270. [CrossRef]

56. Coe, J.A.; Michael, J.A.; Crovelli, R.A.; Savage, W.Z.; Laprade, W.T.; Nashem, W.D. Probabilistic assessment of precipitation-triggered landslides using historical records of landslide occurrence, Seattle, Washington. Environ. Eng. Geosci. 2004, 10, 103-122. [CrossRef]

57. Ibsen, M.L.; Brunsden, D. The nature, use and problems of historical archives for the temporal occurrence of landslides, with specific reference to the south coast of Britain, Ventnor, Isle of Wight. Geomorphology 1996, 15, 241-258. [CrossRef]

58. Lang, A.; Moya, J.; Corominas, J.; Schrott, L.; Dikau, R. Classic and new dating methods for assessing the temporal occurrence of mass movements. Geomorphology 1999, 30, 33-52. [CrossRef]

59. Glade, T. Landslide hazard assessment and historical landslide data - an inseparable couple. In The Use of Historical Data in Natural Hazard Assessments; Glade, T., Frances, F., Albini, P., Eds.; Springer: Dordrecht, The Netherlands, 2001; Volume 17, pp. 153-168. [CrossRef]

60. Corominas, J.; Copons, R.; Vilaplana, J.M.; Altimir, J.; Amigó, J. Integrated Landslide Susceptibility Analysis and Hazard Assessment in the Principality of Andorra. Nat. Hazards 2003, 30, 421-435. [CrossRef] 
61. Dai, F.C.; Lee, C.F. Landslide characteristics and, slope instability modeling using GIS, Lantau Island, Hong Kong. Geomorphology 2002, 42, 213-228. [CrossRef]

62. Qi, S.W.; Xu, Q.; Zhang, B.; Zhou, Y.D.; Lan, H.; Li, L.H. Source characteristics of long runout rock avalanches triggered by the 2008 Wenchuan earthquake, China. J. Asian Earth Sci. 2011, 40, 896-906. [CrossRef]

63. Xu, C.; Shyu, J.B.H.; Xu, X.W. Landslides triggered by the 12 January $2010 \mathrm{Mw} 7.0$ Port-au-Prince, Haiti, earthquake: Visual interpretation, inventory compiling and spatial distribution statistical analysis. Nat. Hazards Earth Syst. Sci. 2014, 2, 1259-1331. [CrossRef]

64. Corominas, J. The angle of reach as a mobility index for small and large landslides. Can. Geotech. J. 1996, 33, 260-271. [CrossRef]

65. Parise, M.; Jibson, R.W. A seismic landslide susceptibility rating of geologic units based on analysis of characteristics of landslides triggered by the 17 January, 1994 Northridge, California earthquake. Eng. Geol. 2000, 58, 251-270. [CrossRef]

(C) 2020 by the authors. Licensee MDPI, Basel, Switzerland. This article is an open access article distributed under the terms and conditions of the Creative Commons Attribution (CC BY) license (http://creativecommons.org/licenses/by/4.0/). 